\title{
Optimization of Wastewater Anaerobic Digestion Using Mechanistic and Meta-heuristic Methods: Current Limitations and Future Opportunities
}

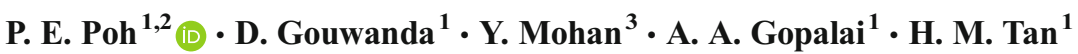

Received: 10 September 2015 / Accepted: 24 December 2015 /Published online: 5 May 2016

(C) Springer Science+Business Media Singapore 2016

\begin{abstract}
Anaerobic digestion is widely used to treat highstrength wastewater and produces methane as a by-product for power generation. Treatment and reuse of industrial effluent also contribute to water conservation efforts. Nevertheless, the sensitivity of anaerobic digestion system proves to be a challenge in ensuring consistent quality of treated wastewater and biogas production. Hence, it is essential to devise an effective model and control system that accurately represent the dynamics of anaerobic digestion and can respond to changes in process parameters with proper fault detection and output prediction. This article provides a comprehensive review on (1) the anaerobic digester technology and parameters governing its efficiency, (2) mechanistic and meta-heuristic models used to describe this process, and (3) the process control strategies. In this study, adaptive controller was found to be able to provide wider options in terms of controlled and manipulated variables. Nevertheless, an in-depth study is essential to determine the best controller to be applied for a
\end{abstract}

Electronic supplementary material The online version of this article (doi:10.1007/s41101-016-0001-3) contains supplementary material, which is available to authorized users.

P. E. Poh

poh.phaik.eong@monash.edu

1 School of Engineering, Monash University Malaysia, Jalan Lagoon Selatan, 47500 Bandar Sunway, Selangor, Malaysia

2 Sustainable Water Alliance, Advanced Engineering Platform, Monash University Malaysia, Jalan Lagoon Selatan, 47500 Bandar Sunway, Selangor, Malaysia

3 Lee Kong Chian Faculty of Engineering and Science, Department of Mechatronics and Biomedical Engineering, Universiti Tunku Abdul Rahman Sungai Long Campus, Jalan Sungai Long, Bandar Sungai Long, 43000 Cheras, Selangor, Malaysia particular system where further optimization can be done to achieve the best performance.

Keywords Anaerobic digestion - Wastewater treatment . Process control $\cdot$ Meta-heuristic $\cdot$ Modelling

\section{Introduction}

Anaerobic digestion is widely used for the treatment of wastewater with high organic carbon content, as an alternative to aerobic digestion [1]. Utilization of anaerobic digestion for treatment of high-strength wastewater reduces the production of sludge while producing methane as a by-product that can be used for power generation [2]. Additionally, anaerobic digestion of wastewater is an effort to conserve water in many areas with arid conditions, where the treated effluent can be reused within the process plant to reduce freshwater consumption.

Biogas generated from anaerobic digestion could potentially offset the anthropogenic carbon dioxide emission from industries and reduce reliance on fossil fuel. Furthermore, industries could gain additional revenue by utilizing biogas produced from anaerobic digestion of wastewater. As an example, four palm oil mills in Malaysia were approved to connect electricity generated from utilization of biogas to national grid. It is expected that a typical palm oil mill processing 60 tonnes/ $\mathrm{h}$ of fresh fruit bunch could gain a net profit of up to RM 3.8 million (1 million USD) annually from producing grid electricity [3].

Nevertheless, anaerobic digestion is a complex process, which involves the use of bacteria that are sensitive to changes in operating conditions [4]. The implementation of anaerobic digestion is further complicated as the characteristics and flow rate of wastewater into the treatment plant are rarely 
consistent-making it a challenge to maintain and control optimal operating conditions for the anaerobic bacteria [5].

There is therefore a need to devise an effective control system capable of responding to changes in wastewater characteristics and operating condition of the treatment plant. Implementation of an effective control system, within the plant, would also see improvement and stabilization in the composition of biogas. This improvement will increase efficiency of the internal combustion engines and minimizes corrosion to the pipeline and other equipment due to higher concentration of hydrogen sulfide [6].

Fault detection and output prediction are indispensable methods in process control. These methods are used to manage production rate of biogas and quality of treated wastewater from anaerobic digesters. The application of appropriate model and process control can maximize the process efficiency, improve sustainability of plant operation, and encourage more parties to adopt anaerobic wastewater treatment systems, eventually leading to a reduction in greenhouse gas emissions. Despite extensive studies in modelling and optimization of anaerobic digester [7-9], many recent developments on anaerobic digestion technology and process control were not thoroughly reviewed in recent years. These studies also did not discuss the use of several meta-heuristic approaches in modelling and control of the digester. Meta-heuristic started gaining traction in recent years and has been used in various applications. Hence, it is important to conduct a comprehensive review in this area to provide proper insight to decision makers for effective handling of wastewater processes to reduce operational costs. Therefore, this review serves to identify the advances in anaerobic digestion of wastewater, modelling, and process control of these systems from year 2000 onwards.

The subsequent section ("Anaerobic Digestion and Digester Technology" section) evaluates various high-rate anaerobic digesters that were utilized for wastewater treatment and latest developments involved. The mechanistic and metaheuristic models that were used to describe anaerobic digestion are thoroughly discussed in "Process Parameters in Anaerobic Digestion" and "Mechanistic Model" sections. "Meta-heuristic Model" discusses the use of several control strategies to improve the performance of the system. Lastly, "Process Control of Anaerobic Digester" identifies the various challenges and opportunities for development of automated anaerobic digesters for industrial wastewater treatment. All these areas assessed by this review paper contribute to water conservation as the utilization of process control methods and automation of industrial wastewater treatment processes produce treated water with higher quality that can be used for recycle and reuse within the industry. In addition, the implementation of process control engineers a wastewater treatment system that can adapt with movable effluent discharge targets set by regulatory bodies.

\section{Anaerobic Digestion and Digester Technology}

Anaerobic digestion is a biological process which involves the use of microbes to degrade complex organic matters (i.e., carbohydrates, proteins, lipids) in the absence of oxygen to methane, carbon dioxide, and water. This process involves a sequence of reactions which includes hydrolysis, acidogenesis, acetogenesis, and methanogenesis using a mixed consortium of bacteria [10, 11]. Anaerobic digestion is often selected over aerobic digestion to treat high-strength industrial wastewater because it is less energy intensive and has higher pathogen inactivation rate. Furthermore, the byproduct of this treatment, methane, can be used for power generation. These characteristics are beneficial for areas/ countries with limited energy source. They can reduce fossil fuel for boilers and other energy-intensive equipment, hence, reducing overheads of industrial processes [3].

Conventional anaerobic digester (for wastewater) was conducted in anaerobic ponds complemented with facultative and aerobic ponds to ensure sufficient removal of organic materials and pathogens $[4,12,13]$. However, this method requires long retention time and large treatment area. As such, high-rate anaerobic reactors were introduced to provide high sludge retention and sufficient contact between bacteria and substrate (wastewater), which minimizes the duration of this treatment and space requirement [14].

Continuous stirred tank reactors (CSTRs) are the least efficient type of anaerobic reactors as they operate at longer hydraulic retention time (HRT) and similarly contribute to lower efficiency in the removal of contaminants. Though CSTR has a relatively simple design, the mechanical agitation can be the contributing factor to the reduced performance of the reactor. The shearing effect induced at rapid mixing can destroy the microbial cells. Additionally, more oxygen will be present in the reactor if the CSTR is not operated at a strict anaerobic condition [10]. Furthermore, it is difficult to ensure that wastewater is well mixed when it is implemented in large scale with larger volume of feed. As such, pilot or industrial scale CSTRs tend to operate at a lower efficiency as compared to laboratory scale CSTRs [15-17].

Upflow anaerobic sludge blanket (UASB) reactors can consistently remove contaminants from industrial wastewater and can achieve an efficiency of up to $97 \%$ of chemical oxygen demand (COD) removal in addition to the production of biogas with at least $60 \%$ of methane concentration. However, foaming, sludge floatation, and granulation inhibition can be present when system is operated at high organic loading rates (OLRs) or when the wastewater contains high concentration of volatile fatty acid (VFA) [18-20]. Besides, high concentration of fats, oil, and grease, phenolic compounds in certain industrial wastewaters, and residual antibiotics in pharmaceutical were reported to cause inhibition in anaerobic digestion [21-24]. This is apparent for the treatment of coal gasification wastewater (as shown in Table 1) where 
Table 1 Performance of various anaerobic reactors for industrial wastewater treatment

\begin{tabular}{|c|c|c|c|c|c|c|}
\hline Wastewater & Reactor type & $\begin{array}{l}\text { Organic loading } \\
\text { rate }(\mathrm{OLR})(\mathrm{kg} \\
\left.\mathrm{COD} / \mathrm{m}^{3} \text { day }\right)\end{array}$ & $\begin{array}{l}\text { Hydraulic } \\
\text { retention time } \\
\text { (HRT) (days) }\end{array}$ & $\begin{array}{l}\text { Maximum COD } \\
\text { removal } \\
\text { efficiency }(\%)\end{array}$ & $\begin{array}{l}\text { Methane } \\
\text { concentration } \\
(\%)\end{array}$ & References \\
\hline \multirow{4}{*}{$\begin{array}{l}\text { Slaughterhouse } \\
\text { wastewater }\end{array}$} & Anaerobic baffled reactor & - & 3.8 & 90 & - & {$[25]$} \\
\hline & Upflow anaerobic filters & 10.05 & 0.5 & 79 & $46-56$ & {$[26]$} \\
\hline & Anaerobic lagoons & - & $5-10$ & 96 & - & {$[27]$} \\
\hline & $\begin{array}{l}\text { Upflow anaerobic sludge } \\
\text { blanket/anaerobic } \\
\text { sequencing batch reactor }\end{array}$ & $1.82-12.79$ & 1 & 94.31 & - & {$[28]$} \\
\hline Grease trap waste & 3-stage packed bed upflow & 21.2 & 1 & 81 & 81 & [29] \\
\hline $\begin{array}{l}\text { Coal gasification } \\
\text { wastewater }\end{array}$ & UASB & 2.5 & 1 & 60 & - & {$[24]$} \\
\hline \multirow{2}{*}{ Swine wastewater } & \multirow[t]{2}{*}{ CSTR (pilot scale) UASB } & 2.5 & 20 & 65.3 & - & {$[15]$} \\
\hline & & 1.0 & 8 & 85.4 & 66 & {$[30]$} \\
\hline $\begin{array}{l}\text { Pharmaceutical } \\
\text { wastewater }\end{array}$ & Hybrid UASB reactor & 9.0 & 1.5 & 75 & 70 & {$[31]$} \\
\hline Brewery wastewater & Fluidized bed & 10.0 & - & 90 & - & {$[32]$} \\
\hline \multirow{3}{*}{$\begin{array}{l}\text { Wash water from virgin } \\
\text { olive oil purification }\end{array}$} & CSTR & $0.86-5.38$ & $4-25$ & - & - & {$[33]$} \\
\hline & $\begin{array}{l}\text {-With biomass immobilized on } \\
\text { bentonite }\end{array}$ & & & & & \\
\hline & -Suspended biomass & $0.86-4.30$ & $5-25$ & & & \\
\hline \multirow{3}{*}{$\begin{array}{l}\text { Palm oil mill effluent } \\
\text { (POME) }\end{array}$} & UASB-HCPB & 27.65 & 2 & 90 & 60 & {$[34]$} \\
\hline & UASFF & 8.74 & 3 & 97.5 & 74.2 & {$[35]$} \\
\hline & EGSB & $2.9^{\mathrm{a}}$ & 5 & 95.5 & 66 & {$[36]$} \\
\hline
\end{tabular}

$U A S F F$ upflow anaerobic sludge fixed film, $U A S B-H C P B$ upflow anaerobic sludge blanket-hollow centered packed bed, $E G S B$ expanded granular sludge bed

${ }^{\mathrm{a}}$ Units are quoted in gram volatile solid per liter per day

the COD removal efficiency $(60 \%)$ is lower than any other wastewater treated using UASB reactor due to the presence of phenolic compounds. Thus, it is essential to consistently monitor the composition of wastewater entering the reactor and to implement appropriate control to ensure satisfactory removal of contaminants from wastewater.

In order to counter operational issues due to foaming, washout of biomass, VFA, and toxic compound inhibition in anaerobic digestion and to simultaneously boost contaminant removal and biogas production, researchers have ventured into the development of hybrid anaerobic reactors, multistage anaerobic reactors, and anaerobic co-digestion $[15,23$, $34,35]$. One of the reactors which is highly suitable for application in palm oil mill effluent (POME) treatment would be upflow anaerobic sludge blanket-hollow centered packed bed (UASB-HCPB) which has a COD removal efficiency of $90 \%$, suspended solid removal capability of $80 \%$, and a biogas production which consists of $60 \%$ methane concentration when operated under thermophilic condition with an OLR of $27.65 \mathrm{~g} \mathrm{~L}^{-1}$ day $^{-1}$ and an HRT of 2 days [34]. Another alternative would be the application of a hybrid anaerobic reactor (upflow anaerobic sludge fixed film (UASFF)) [35] for POME treatment which shows notable improvement in the COD removal efficiency and methane concentration (Table 1). Similar outcome was reported by Hunter et al. [37] and $\mathrm{Ke}$ et al. [38] where multi-staged anaerobic reactor showed superior performance over single-stage anaerobic reactor. However, these systems are more difficult to implement as they involve many different process parameters that can influence their performances [38].

\section{Process Parameters in Anaerobic Digestion}

Regardless of the type of anaerobic digester used for wastewater treatment, it is essential to understand various process parameters that can influence the operational performance of high-rate anaerobic reactors to ensure that proper control system can be devised based on the conditions of the process. In this review, the focus is on the process parameters that are highly influential towards the performance of high-rate anaerobic reactors. These parameters are commonly used variables when devising anaerobic digester models and control strategies to improve quality of treated wastewater and biogas production. 


\section{Temperature}

Microbes can optimally operate at three different temperature ranges - psychrophilic $\left(<20^{\circ} \mathrm{C}\right)$, mesophilic $\left(>25^{\circ} \mathrm{C}\right)$, and thermophilic $\left(50-60^{\circ} \mathrm{C}\right)$. Temperature is an important parameter in maintaining performance of an anaerobic digester as it governs bacterial growth and activity [14]. Several studies conducted to investigate the effect of temperature found that digester operating at the thermophilic region $\left(55^{\circ} \mathrm{C}\right)$ has several advantages: higher substrate degradation, higher biogas production rate, and the ability to operate under higher OLRs at shorter HRTs [39-41]. Higher biogas production rate is crucial to the operation of anaerobic digester as it is able to reduce the return of investment [42].

Nevertheless, biomass washout with accumulation of VFA could occur if the digester is not controlled to operate at its optimal temperature [43]. This is due to the fact that methanogenesis reaction that consumes VFA proceeds at a lower rate in comparison to the acidogenic reaction that produces VFA. When the anaerobic digester is operated in the thermophilic region, the rate of VFA production will increase. When it is coupled with other conditions such as high OLR and HRT, the methanogens will not have sufficient time to multiply or to convert the accumulated VFA in the system, causing biomass washout. Therefore, temperature of the digester should be strictly maintained to ensure optimal performance during anaerobic digestion of wastewater.

\section{pH and Volatile Fatty Acid Concentration}

$\mathrm{pH}$ is another crucial parameter that needs to be monitored and controlled to maintain good performance of an anaerobic digester. This is attributed to the microbial community that is sensitive to $\mathrm{pH}$ changes. As such, most anaerobic digesters (except two/multiple-stage digesters) operate at an optimal $\mathrm{pH}$ of 6.8-7.2 as this range of $\mathrm{pH}$ is optimal for the growth of methanogens that produces methane as the main product. On the other hand, $\mathrm{pH}$ lower than 4 and higher than 9.5 is not advisable as methanogenesis can occur at a lower rate at lower $\mathrm{pH}$, leading to the accumulation of VFA, which will eventually lead to failure of the anaerobic digester [11, 44]. Furthermore, reduction of $\mathrm{pH}$ (from alkaline to neutral region) was reported to be able to reduce ammonia toxicity within the digester, ensuring that VFA in the system could be properly utilized for the conversion to methane [2]. $\mathrm{pH}$ of anaerobic digester is commonly controlled to be below 10 as at higher $\mathrm{pH}$ (between 9 and 10) the treated effluent may not conform to the effluent discharge limit [10].

\section{Organic Loading Rate (Dilution Rate) and Hydraulic Retention Time}

OLR and dilution rate are interchangeable terms that represent the load of contaminants fed into the anaerobic digester. OLR is determined via the COD or volatile solid concentration per unit time, per volume of digester, while dilution rate represents the flow rate of contaminants per volume of culture in the digester. Values of OLR are generally dependent on the "strength" of wastewater. OLR and HRT are inter-related in the operation of an anaerobic digester. The operating HRT and concentration of organic substance can influence the OLR of a system. Anaerobic digesters have to be operated at high OLR if the wastewater fed into the reactor has high concentration of COD and is retained in the digester for a short period of time (short HRT).

Generally, it is desired to operate an anaerobic digester at high OLRs as the output of biogas from the system increases. Nevertheless, investigations on anaerobic treatment of various industrial wastewaters found that an increase in OLR was shown to cause the performance of anaerobic digesters to decline [12]. This is mainly due to the fact that microbial population in the anaerobic digester could not convert substrates on time, thus leading to lower COD removal efficiencies and accumulation of VFA. Therefore, wastewater concentration and the flow rate should be closely monitored and controlled to avoid reactor upsets. Despite understanding the relationship between OLR and HRT, it is not possible to suggest an optimum OLR for the anaerobic digestion of all types of wastewater as the tolerable OLR is very much dependent on the level of contamination of the wastewater, the inhibitory compounds, and other operating condition, e.g., temperature and rate of mixing that will affect the growth of the microbial population in the digester.

\section{Other Parameters Influencing Anaerobic Digestion}

There are several other parameters that could inhibit the operation of anaerobic digesters such as metal toxicity [45-47], presence of herbicides, pharmaceutical components, overloading of macronutrients [2, 48], and unconsumed hydrogen. These factors can result in high hydrogen partial pressure which inhibits acetogenesis phase, in particular the conversion of long chain fatty acids into acetate and propionate [49]. Therefore, it is extremely important that the wastewater is carefully characterized prior to the design of wastewater treatment system and development of the process control system so that proper operating conditions and operating set points can be devised.

\section{Mechanistic Model}

In order to develop an effective control system for anaerobic digester, suitable mathematical model that can describe the dynamics of continuous anaerobic digestion and the interaction between controlled parameters described in "Process Parameters in Anaerobic Digestion" is crucial. Several mechanistic models had been proposed to describe this process, 
including early models proposed by Bailey and Ollis [50], Pavlostathis et al. [51], and Denac et al. [52] and the popular mass balance model developed by Bernard et al. [53] and Anaerobic Digestion Model No. 1 (ADM-1) by Batstone [54].

\section{Mass Balance Model}

Various anaerobic digestion models were proposed and reported in literature - ranging from models with great complexity which can be difficult to be physically implemented to models with assumptions that are not necessarily present in practice [53]. This disparity can be attributed to the lack of phenomenological knowledge, nonlinearity, and complexity of the process itself. The mass balance model circumvented these limitations by modelling and focusing on the reaction rates and minimizing the number of assumptions. Bastin and Dochain [55] were pioneers in reporting the effectiveness of the mass balance model.

Mass balance model proposed and validated by Bernard et al. [53] is one of the widely accepted models to simulate anaerobic digesters. Their model was devised from several variables such as concentration of biomass, total organic carbon (TOC), COD, VFA, and alkalinity. It was developed with the following assumptions: (i) $\alpha$ was introduced to consider the process heterogeneity. $\alpha=1$ describes the dynamics of the classical CSTR where the biomass is completely suspended in the liquid phase. $0<\alpha<1$ describes the dynamics of fluidizedbed reactors or fixed-bed reactors (FBRs); (ii) it is considered that the alkalinity is mainly due to the concentration of bicarbonate and VFA; and (iii) it is assumed that the anaerobic digestion operates under isothermal condition. Other than being validated in their own experimental study, the Bernard et al. [53] model was seen to be consistent with a wider range of experimental verifications too [56-60].

The mass balance model is derived from a macroscopic mass balance of key variables of the process, and details of the model are presented in Bernard et al. [53] as shown in Table 2. In order to derive the control scheme for mass balance models, destabilization criteria were considered. The destabilization of anaerobic digestion processes primarily involves the development of unbalanced microbial consortia leading to a high concentration of VFA and eventually a total system failure. Therefore, VFA concentration has been proposed to be one of the reliable indicators of system's operation and performance. Choosing VFA as the variable to be controlled would result in the basic dynamical model of Eq. 1

Variations to the Bernard et al. [53] model were proposed by Mendez-Acosta et al. [61], Rincon et al. [60], and FloresEstella et al. [5]. Mendez-Acosta et al. [61] sought to control anaerobic digestion by regulating VFA and total alkalinity (TA) as these were deemed to be the main parameters that led to washout. To achieve this, they used different assumptions to control the inlet parameters. This view was also shared by Rincon et al. [60], where the authors reported a mass balance model seeking to regulate VFA to avoid total system failure. However, the ability of the model to perform in dynamic conditions (destabilization phases) cannot be concluded as both studies were based on simulation and mathematical prediction with no physical verification being conducted. Another mass balance model specifically for the winery industry was reported by Flores-Estrella et al. [5]. In this model, Flores-Estrella et al. [5] sought to control the COD as it was

Table 2 Mass balance equation

\begin{tabular}{|c|c|c|}
\hline & Mass balance equation & Prefix \\
\hline \multirow[t]{7}{*}{1} & $X_{1}=X_{1}\left(\mu_{1}-\alpha D\right)$ & 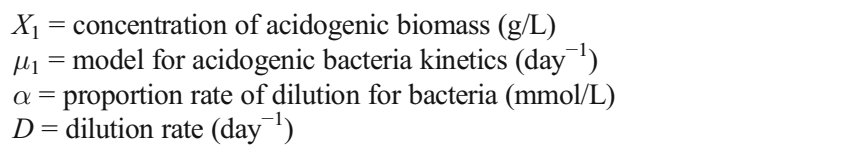 \\
\hline & $X_{2}=X_{2}\left(\mu_{2}-\alpha D\right)$ & $\begin{array}{l}X_{2}=\text { concentration of methanogenic biomass }(\mathrm{g} / \mathrm{L}) \\
\mu_{2}=\text { model for methanogenic bacteria kinetics }\left(\text { day }^{-1}\right)\end{array}$ \\
\hline & $S_{1}=\left(S_{1}^{\mathrm{in}}-S_{1}\right) D-k_{1} \mu_{1} X_{1}$ & $\begin{array}{l}\mathrm{S}_{1}=\text { organic substrate characterized by its } \mathrm{COD}(\mathrm{g} \mathrm{COD} / \mathrm{L}) \\
k_{1}=\text { yield for substrate degradation (unitless) }\end{array}$ \\
\hline & $S_{2}=\left(S_{2}^{\mathrm{in}}-S_{2}\right) D^{-}$ & $\mathrm{S}_{2}(t)$ represents the concentration of VFA $(\mathrm{mmol} / \mathrm{L})$ \\
\hline & $\mathrm{N}_{2}-\left(\mathrm{N}_{2}-\mathrm{J}_{2}\right)^{2}$ & $k_{2}$ yield for VFA production $(\mathrm{mmol} / \mathrm{g})$ \\
\hline & & $k_{3}$ yield for VFA consumption $(\mathrm{mmol} / \mathrm{g})$ \\
\hline & $\mu_{1}=\mu_{1 \max } \frac{S_{1}}{S_{1}+K_{\mathrm{s} 1}}$ & $\begin{array}{l}\mu_{1 \max }=\text { maximum bacterial growth rate }\left(\text { day }^{-1}\right) \\
K_{\mathrm{s} 1}=\text { half saturation constant which depends on the substrate, } S_{1}(\mathrm{~g} / \mathrm{L})\end{array}$ \\
\hline 2 & $\mu_{2}=\mu_{2 \max } \frac{S_{2}}{S_{2}+K_{\mathrm{s} 2}+\left(\frac{1}{K_{12}}\right) S_{2}^{2}}$ & $\begin{array}{l}\mu_{2 \max }=\text { growth rate of bacteria at its maximum without inhibition }\left(\text { day }^{-1}\right) \\
K_{\mathrm{s} 2}=\text { saturation constant which depends on the substrate } S_{2}(\mathrm{mmol} / \mathrm{L}) \\
K_{\mathrm{I} 2}=\text { inhibition constant which depends on substrate } S_{2}(\mathrm{mmol} / \mathrm{L})\end{array}$ \\
\hline
\end{tabular}


argued to be the fundamental objective in water treatment plants.

The monitoring of anaerobic digestion is admittedly difficult and complex, as it is a multivariate process. This is further complicated with limited reliable online sensors for the measurement of all required parameters and substances involved [62]. The mass balance model, however, is mainly interested in monitoring one or all of the following (1) COD, (2) VFA, and the (3) reduction of model complexity. This is where this model is advantageous, by limiting the number of parameters required and assumptions made. Moreover, it ensures reliable and extended time periods of useful operations.

\section{Anaerobic Digestion Model No. 1}

Apart from the mass balance model, ADM-1 is also commonly incorporated to develop model-based control for anaerobic digestion systems. ADM-1 is a mechanistic model developed with the purpose of creating a common platform for anaerobic process modelling and simulation that could encourage greater utilization of anaerobic process technologies in the future [54]. It can also be used to develop operational strategies and evaluate controllers [63]. The ADM-1 model incorporates all three biochemical steps (i.e., hydrolysis, acidogenesis, acetogenesis, and methanogenesis) and physico-chemical steps such as ion association/dissociation and gas-liquid transfer.

ADM-1 is modelled after a CSTR of 32 dynamic state concentration variables, where 24 of them are described using first-order Monod kinetics with a general form as shown in the equation below, where $S_{i}$ is the component concentration $(\mathrm{kg}$ $\left.\operatorname{COD~m^{-3}}\right), q$ is the flow $\left(\mathrm{m}^{3}\right.$ day $\left.^{-1}\right), V_{\text {liq }}$ is the volume of the reactor $(\mathrm{m})$, and the kinetic rates $\rho_{j}$ for process $j\left(\mathrm{~kg} \mathrm{COD} \mathrm{m}^{-3}\right.$ day $^{-1}$ ) multiplied by the stoichiometric biochemical rate coefficients $v_{i, j}$

$\frac{d S_{\mathrm{liq}, i}}{d t}=\frac{q_{\mathrm{in}} \cdot S_{\mathrm{in}, i}}{V_{\mathrm{liq}}}-\frac{q_{\mathrm{out}} \cdot S_{\mathrm{liq}, i}}{V_{\mathrm{liq}}}+\sum_{j=1-19} \rho_{j} \cdot V_{i, j}$

$($ Accumulation $=$ Input-Output + Reaction $)$

ADM-1 has been applied to simulate and control UASB reactor [64], to devise fuzzy-based controller of anaerobic reactor [65], and to develop multi-objective cascade controllers for anaerobic digester [66]. This model has become available in simulation software, such as MATLAB, Simulink, WEST, BioWin, and Aquasim [67] to ease its application. In some cases, ADM-1 was also modified to extend the application of this model to simulate anaerobic digestion involving ethanol degradation pathways [68, 69], anaerobic digestions which involve precipitation of $\mathrm{CaCO}_{3}[70]$ and modifications which focus on hydrolysis kinetics [71].
ADM-1 is undeniably the most robust model that has been applied to develop control schemes for anaerobic digestion. However, for its implementation, it is crucial to have a comprehensive characterization of the substrate. This can be difficult for anaerobic digestion with significant variation in feed characteristics throughout the year, especially in wastewater treatment processes. For example, the olive mill wastewater (OMW) characteristics would vary greatly between mills [72, 73], and in the case of POME, it would vary according to season and type of fruits processed in the mill [73]. This could reduce the robustness of the control systems developed for such systems, and hence future development should be focused on the modification of ADM-1 to cater for wastewaters with varying characteristics.

\section{Meta-Heuristic Model}

Other than mechanistic models, researchers have also attempted to design and develop models based on metaheuristic approaches, such as fuzzy logic, artificial neural network (ANN), particle swarm optimization (PSO), and their combinations.

\section{Fuzzy Logic Model}

Fuzzy logic modelling represents a linguistic model approach in describing domain knowledge (Fig. 1) [74]. Fuzzy logic models are superior in terms of the ease in increasing the number of input parameters it can monitor. This is because each input parameter will be modelled into a fuzzy set, simplifying the real-world representation by eliminating the need for crisp set theory. The basic idea of the fuzzy set theory is that an element belongs to a fuzzy set with a certain degree of membership. For example, a proposition is not either just true or false but may be partly true (or partly false) to any degree (membership function). Such approach allows for knowledge to be represented efficiently on a computer as a model. The membership functions of the input parameters will then be analyzed via a set of "if-then" rules to determine an appropriate output. Precision of the information evaluated can be improved through alteration of membership function which would provide a higher degree of accuracy in addition to alteration done on the "if-then" rules. The ability of the fuzzy logic model to handle ambiguity via membership functions and "if-then" rules make fuzzy logic ideal for bioprocesses and chemical engineering processes which are very dynamic in nature [29, 75, 76].

Application of fuzzy logic in AD can be seen in works presented in Giraldo-Gomez and Duque [21], Boscolo et al. [77], Mingzhi et al. [78], and Steyer et al. [79], TurkdoganAydinol and Yetilmezsoy [80], and Varne and Macwan [81]. In recent publications, Turkdogan-Aydinol and Yetilmezsoy 


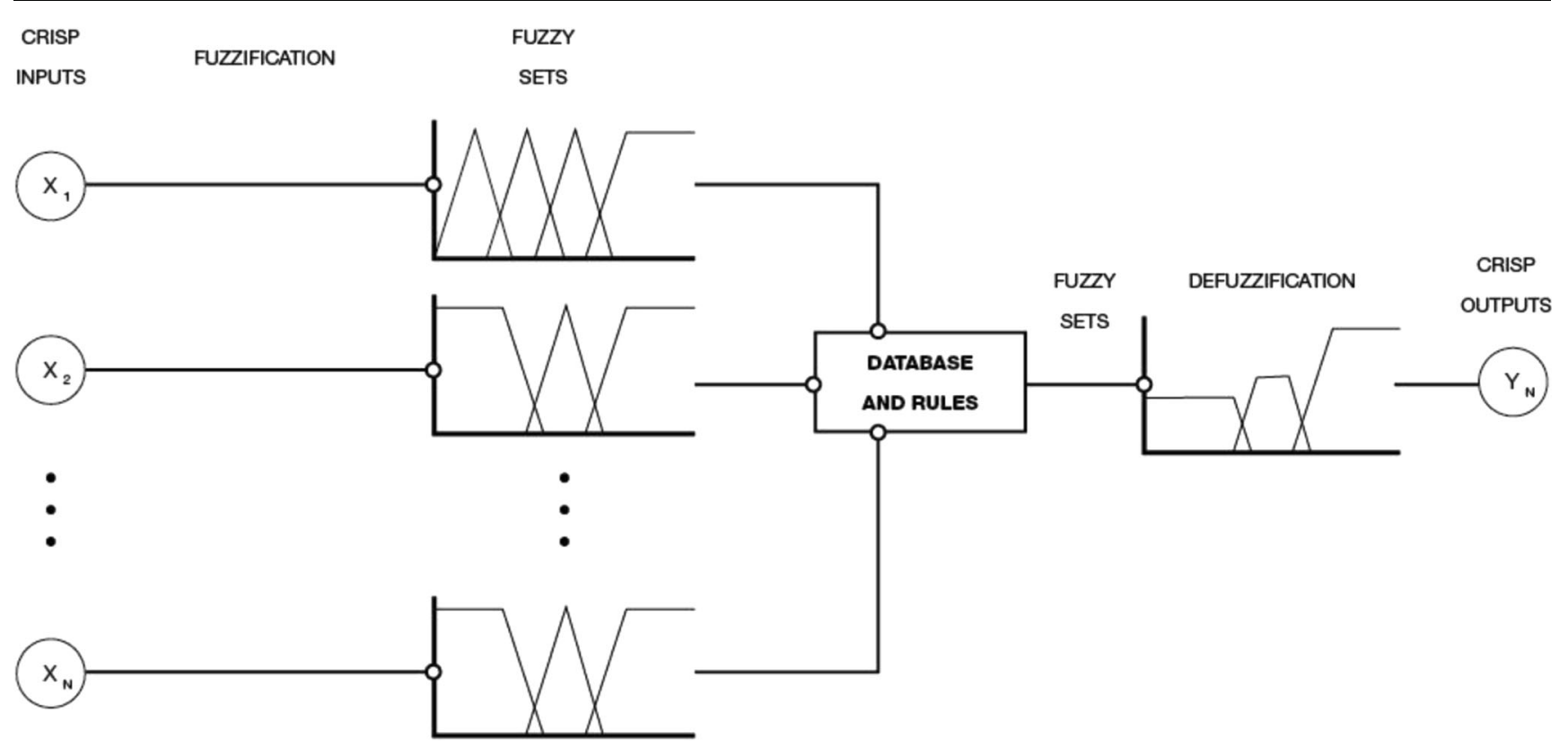

Fig. 1 Mamdani fuzzy logic model

[80] developed fuzzy model to predict biogas and methane production rates in molasses wastewater treatment. They used Mamdani's fuzzy inference method with five input variables, i.e., volumetric OLR, volumetric COD, removal rate, influent alkalinity, and influent and effluent $\mathrm{pH}$. On the other hand, Varne and Macwan [81] developed fuzzy model to predict COD reduction and biogas production rate using flow rate, influent $\mathrm{COD}, \mathrm{pH}$, and temperature.

Use of fuzzy logic in AD brings several advantages.

1. Fuzzy logic can handle a large number of inputs allowing optimum operational condition to be attained without the need to rely solely on the experience of operators.

2. Fuzzy logic can rationally quantify uncertainty in systems and qualitative behavior of the system.

3. Fuzzy logic can handle greater sensitivity and instability poised by $\mathrm{AD}[82]$.

4. Fuzzy logic allows consistent generation of biogas [13].

One of the main concerns in implementing a fuzzy logic model is that it evaluates relationship between the parameters defined in the system (inputs and output) via a set of "if-then" rules, which may be seen to oversimplify the dynamics of the digestion system. However, in terms of physiochemical and biological changes, it is important that biomass activity occurring during anaerobic digestion is taken into account during the analysis $[5,75]$. The other concern is the nonsystematic initial tuning approach [29]. Trial and error tuning has to be continuously done as a fuzzy logic model can be compared to a black box model which is nontransparent and highly complex. The tuning procedure may vary depending on the type of bacteria, temperature, and the phase of the reaction. However, once a general model is established, future tuning is simple as it uses normal human language that is easily understandable for the operators.

\section{ANN}

ANN is a collection of "neurons," and the properties of the network are determined by its topology and the properties of the neurons. Being inspired by the human nervous system, ANN was developed by interconnecting models which would give similar behavior to biological neurons. Instead of depending on the prior knowledge or the need to list the correlations between parameters, ANN is a self-learning model which allows prediction of output that is considerably of higher versatility compared to other logical operation system. The abstract properties of ANN, such as their ability to perform distributed computation, to tolerate noisy inputs, and to learn, have attracted the interest of researchers in various problem domains, including anaerobic digestion of wastewater [83]. Structures of ANN can be divided into two main categories, namely the recurrent or feedback networks and feedforward or multi-layer network. The main characteristics of these networks are presented in Table 3.

Training on ANN is executed by three types of learning algorithm, namely supervised, unsupervised, and reinforcement learning. Supervised learning requires supervision in the form of desired outputs to be stated where the weights of interconnectivity between neurons will be adjusted based on the difference between actual and desired output with reference to the input provided. Unsupervised training on the other hand only requires input to be given whereby input patterns with similar features will 
Table 3 Characteristic of recurrent and feedforward network [84]

\begin{tabular}{|c|c|c|}
\hline Network & Recurrent (Feedback) & Feedforward (Multilayer) \\
\hline $\begin{array}{l}\text { Connectivity } \\
\text { between neurons }\end{array}$ & $\begin{array}{l}\text { An interconnecting network } \\
\text { is organized by the } \\
\text { interconnection of multiple } \\
\text { neurons }\end{array}$ & $\begin{array}{l}\text { Multiple layers with a hierarchical } \\
\text { structure where interconnection among } \\
\text { neurons in the same layer are absent in } \\
\text { some layers }\end{array}$ \\
\hline Signal flow & $\begin{array}{l}\text { - Both directions: forward } \\
\text { and backward } \\
\text { - Weights in neurons are } \\
\text { constantly adjusted until a } \\
\text { steady state is reached or } \\
\text { the system exhibits } \\
\text { oscillation or chaotic } \\
\text { behavior. Thus, } \\
\text { application on rapidly } \\
\text { changing of input neurons } \\
\text { is not favored due to } \\
\text { unwanted response and } \\
\text { time wastage } \\
\text { Response of given input } \\
\text { depends on initial stage } \\
\text { (supports short-term } \\
\text { memory) }\end{array}$ & $\begin{array}{l}\text { - Unidirectional connections whereby } \\
\text { signals flow from input to output } \\
\text { layers } \\
\text { - No loops present } \\
\text { - Each neuron consists of only } \\
\text { information of the adjusted weights } \\
\text { from input to output neurons }\end{array}$ \\
\hline Figure & $\begin{array}{l}x_{x}- \\
\text { Inputs }\end{array}$ & $\begin{array}{c}\text { Hidden } \\
\text { layer } \\
\text { layer }\end{array}$ \\
\hline Examples of ANN & $\begin{array}{ll}\text { - } & \text { Hopfield network } \\
\text { - } & \text { Elman network } \\
\text { - } & \text { Jordan network }\end{array}$ & $\begin{array}{ll}\text { - } & \text { Multi-layer perceptron } \\
\text { - } & \text { Learning method quantization } \\
\text { - } & \text { Cerebellar model articulation } \\
& \text { control }\end{array}$ \\
\hline
\end{tabular}

be clustered into groups through adaptability of connections between weights. For reinforcement learning, targeted output is not sought after but instead accuracy of neural network output based on the given input is evaluated instead.
ANN has several advantages. Among them is its processing speed and greater fault tolerance. It has a highly parallel structure that is suitable for real-time dynamic control. Moreover, it also allows implementation of nonlinear control 
problems. Highly adaptable and integrative is another advantage of the ANN. It permits handling of large scale, complex, and system with multivariable. Besides, ANN is not only limited to handling qualitative data but also quantitative data. Lastly, ANN is able to generalize data through training of past data records which is highly useful for processes that are difficult to be handled by descriptive rules or of complicated mathematical models.

Application of ANN on anaerobic digestion modelling is deemed effective [85] as ANN is highly adaptable. This can be viewed in terms of parameter adjustment employed on the system through the design of a cognitive which enables effective changes to be made. In addition, ANN is commonly applied in energy industry. With reference to this observation, it can be inferred that application of ANN in anaerobic digestion is rather efficient as biogas recovery can be considered as a form of renewable energy salvation from waste. Moreover, based on current trend which illustrates the effectiveness of ANN to predict and demonstrate models dealing with unclear mechanistic [71], the efficacy of ANN can be further deduced when utilized in anaerobic digestion system.

A successful application of ANN in control system is the modelling and prediction of bioethanol production [21] which shows a relatively good prediction as the coefficient of determination ( $R^{2}$ value) ranges from 0.800 to 0.999 . This indirectly demonstrates the effectiveness of ANN to be used as a predictive model for anaerobic digestion. The only downside is the need to vary the number of weights to improve $R^{2}$ value. In addition, use of ANN for anaerobic digestion depends on the input and output variables and the type of network used. Holubar et al. [86] trained feedforward back propagation (FFBP) ANN to model and subsequently control methane production in anaerobic digester. They used gas composition, methane production rate, VFA concentration, $\mathrm{pH}$, redox potential, volatile suspended solids, and COD of feed and effluent as the input variables. The output from the network is fed into a decision support system to find out the best feeding profile for the next time steps in advance. Rangasamy et al. [87] used maximum OLR, HRT, and the efficiency of the reactor to determine the effluent $\mathrm{COD}$ and $\mathrm{pH}$, biogas production, VFA, and alkalinity. They proposed the use of multilayer perceptron ANN which has two input neurons, five output neurons, and two hidden layers. Holubar et al. [86] and Rangasamy et al. [87] successfully demonstrated the viability of ANN to model anaerobic digestion. Other issues faced by ANN, summarized in Table 4, are mainly poor generalization of models leading to over fitting.

\section{Particle Swarm Optimization}

PSO has a working principle illustrated in Fig. 2. In contrast to fuzzy logic and ANN, PSO is mainly used to optimize processes instead of direct application as a control process.
Implemented on complex nonlinear and multidimensional functions, the main aim of PSO is to attain global optimum value via convergence [91]. Solutions acquired by particles are differentiated into two main types. In terms of particle basis, a comparison will be made and personal best value will be obtained, whereas global optimum solution is gained in terms of PSO process by global optimization. Speed of convergence relies closely to the size of search space, population size of the swarm, and the number of generations. Representation of the initial population of PSO can be further improved by introducing some rule of thumb or constraints to reduce the search space. Perturbation, such as crossover [92], can also be carried out within PSO to speed up the convergence speed of the algorithm. Rate of change in position of particles is regarded as apparent velocity of the particle which changes according to the translation velocity shown below at each iteration.

$$
\begin{aligned}
v_{N k}^{i+1}= & \omega v_{N k}^{i}+A_{1} \operatorname{rand}(0,1)\left(P_{N k}-X_{N k}\right) \\
& +A_{2} \operatorname{rand}(0,1)\left(G_{N}-X_{N k}\right)
\end{aligned}
$$

where

$$
\begin{array}{ll}
K & \text { Number of particles } \\
X_{k}=\left\{X_{k 1}, X_{k 2}, \ldots, X_{k N}\right\} & \text { Position of } k \text { th particles } \\
P_{k}=\left\{P_{k 1}, P_{k 2}, \ldots, P_{k N}\right\} & \begin{array}{l}
\text { Best visited position of the } \\
k \text { th particles }
\end{array} \\
G=\left\{G_{1}, G_{2}, \ldots, G_{N}\right\} & \text { Best result of all particles in } \\
& \text { PSO algorithm } \\
v_{p}=\left\{v_{p 1}, v_{p 2}, \ldots, v_{p N}\right\} & \text { Apparent velocity of particle } p \\
A_{1} \text { and } A_{2} & \text { Constant \{learning factors; } \\
& \text { acceleration of particles towards } \\
& \text { the best position over the search } \\
& \text { space }\} \\
& \text { Inertia weight }
\end{array}
$$

$\omega$ continuously changes over each iteration according to the equation below:

$\omega_{\mathrm{i}}=\omega_{\max }-\frac{\omega_{\min }}{i_{\max }} \times i$

where

$\omega_{i} \quad$ Inertia weight

$i_{\max } \quad$ Maximum steps of iteration

$\omega_{\max }$ Maximum value of inertia weight

$\omega_{\min }$ Minimum value of inertia weight

Based on empirical studies, acceptable values of $\omega_{\min }=0.4$ while $\omega_{\max }=0.9$ [93].

In compliance with the equations stated above, further fine tuning of PSO is compulsory similar to fuzzy logic. For PSO, algorithmic performance is greatly influenced by the tuning parameter known as exploration and exploitation. Locating a good optimum and more favorably a global optimum solution 
Table 4 Overview of meta-heuristic model [88-90]

\begin{tabular}{|c|c|c|c|}
\hline $\begin{array}{l}\text { Meta-heuristic } \\
\text { model }\end{array}$ & Fuzzy logic & Artificial neural network (ANN) & Particle swarm optimization (PSO) \\
\hline Basis & Derivation of rules & Empirical risk minimization & Population-based strategy \\
\hline Strengths & $\begin{array}{l}\text { - Does not require mathematical } \\
\text { model } \\
\text { - Flexible } \\
\text { - Implementation and } \\
\text { interpretation is relatively } \\
\text { easy, low complexity } \\
\text { - Simple fuzzy sets and } \\
\text { inference rules via linguistic } \\
\text { terms }\end{array}$ & $\begin{array}{l}\text { - No mathematical model is necessary } \\
\text { - Adaptation ability towards minor } \\
\text { environment changes } \\
\text { - Able to handle multiple variables } \\
\text { with multitude functions } \\
\text { - Scalable } \\
\text { - Able to handle multiple constraints } \\
\text { imposed on the system evaluated } \\
\text { - Possess forward propagation mode } \\
\text { once satisfactory trained level of } \\
\text { network is attained that can be used } \\
\text { as an analytical tool on other data } \\
\text { - Minimal data is required }\end{array}$ & $\begin{array}{l}\text { - Calculation required in PSO is } \\
\text { relatively simple } \\
\text { - Adoption of real number code } \\
\text { allowing direct application by } \\
\text { solution whereby dimension } \\
\text { number is equivalent to the solution } \\
\text { constant } \\
\text { - Have the capability to store memory } \\
\text { - No overlapping or mutation } \\
\text { calculation where only the most } \\
\text { optimist particle can transmit info } \\
\text { to other particles which fasten the } \\
\text { research speed }\end{array}$ \\
\hline Weakness & $\begin{array}{l}\text { - Require rule derivation } \\
\text { - Highly dependent on inference } \\
\text { rules that affect accuracy } \\
\text { - Relied on relevancy of rules } \\
\text { and the features }\end{array}$ & $\begin{array}{l}\text { - Requires training data and prior } \\
\text { knowledge of environment } \\
\text { - Training speed is affected by } \\
\text { network size } \\
\text { - Subjected to over-train leading to } \\
\text { output respond which depends } \\
\text { solely only on one input } \\
\text { - Developed model which is not the } \\
\text { general representation of the system } \\
\text { may lead to overfitting } \\
\text { - Local minima may provide multiple } \\
\text { solutions which is not robust for } \\
\text { different samples }\end{array}$ & $\begin{array}{l}\text { - Problems of scattering cannot be } \\
\text { solved } \\
\text { - Optimization process may only be } \\
\text { completed partially } \\
\text { - Problem of noncoordinate system } \\
\text { also could not be solved } \\
\text { - Clustering of data may happen when } \\
\text { the load of data handled is too large }\end{array}$ \\
\hline Challenges & $\begin{array}{l}\text { - Derivation of rules must be } \\
\text { determined accurately which } \\
\text { requires experts' knowledge } \\
\text { during initial stage } \\
\text { - Fine tuning is relatively } \\
\text { difficult as standard } \\
\text { procedure is absent and } \\
\text { requires trial and error } \\
\text { method } \\
\text { - Every possibility for the } \\
\text { system process must be listed } \\
\text { in order to acquire higher } \\
\text { accuracy }\end{array}$ & $\begin{array}{l}\text { - Clean and task relevant data is } \\
\text { necessary during the training phase } \\
\text { - Data and parameters chosen must be } \\
\text { appropriate as training performance } \\
\text { speed are dependent on it }\end{array}$ & $\begin{array}{l}\text { - Weak theoretical foundation where } \\
\text { stable movement of particle is } \\
\text { rather limited } \\
\text { - Suitability of topologies of different } \\
\text { ranges which gives a better function } \\
\text { can be researched on } \\
\text { - Application area of PSO has yet to } \\
\text { be widely used and combination of } \\
\text { PSO with other optimization } \\
\text { algorithm is proposed to give a } \\
\text { better result }\end{array}$ \\
\hline
\end{tabular}

through various region testing is exploration, while concentration of search at specific particles for precise location of optimum is known as exploitation. Although both parameters are favorable and hope to be acquired, a tradeoff is usually necessary among the two as complete theoretical analysis on the two indicates the involvement of mathematical complexity whereby simplified derivation is yet to be found [82].

However, PSO is considered an effective algorithm to be implemented on fuzzy logic or ANN for optimization of anaerobic digestion modelling. This is in line with previous reports which indicated effectiveness of PSO when coupled with ANN. The main advantage of PSO is the ability of each particle to record their best position despite the change in population samples over time. Hence, based on this plus point, high load of data can be handled by PSO and best solution to attain the optimum condition for anaerobic digestion can be found as the best trajectory paths of particles to achieving the global are kept tracked allowing the optimum control condition to be acquired. Smith [94] demonstrated the applicability of PSO in determining the pressure of seven different types of gases present in anaerobic digester: ammonia, carbon dioxide, hydrogen, hydrogen sulfide, methane, nitrogen, and oxygen.

In addition, as the solution is independent of population sample changes, variation in data collected over time can be continuously added to the system to attain the best optimum solution at that point of time. This is highly favored in anaerobic 
Fig. 2 Particle swarm optimization

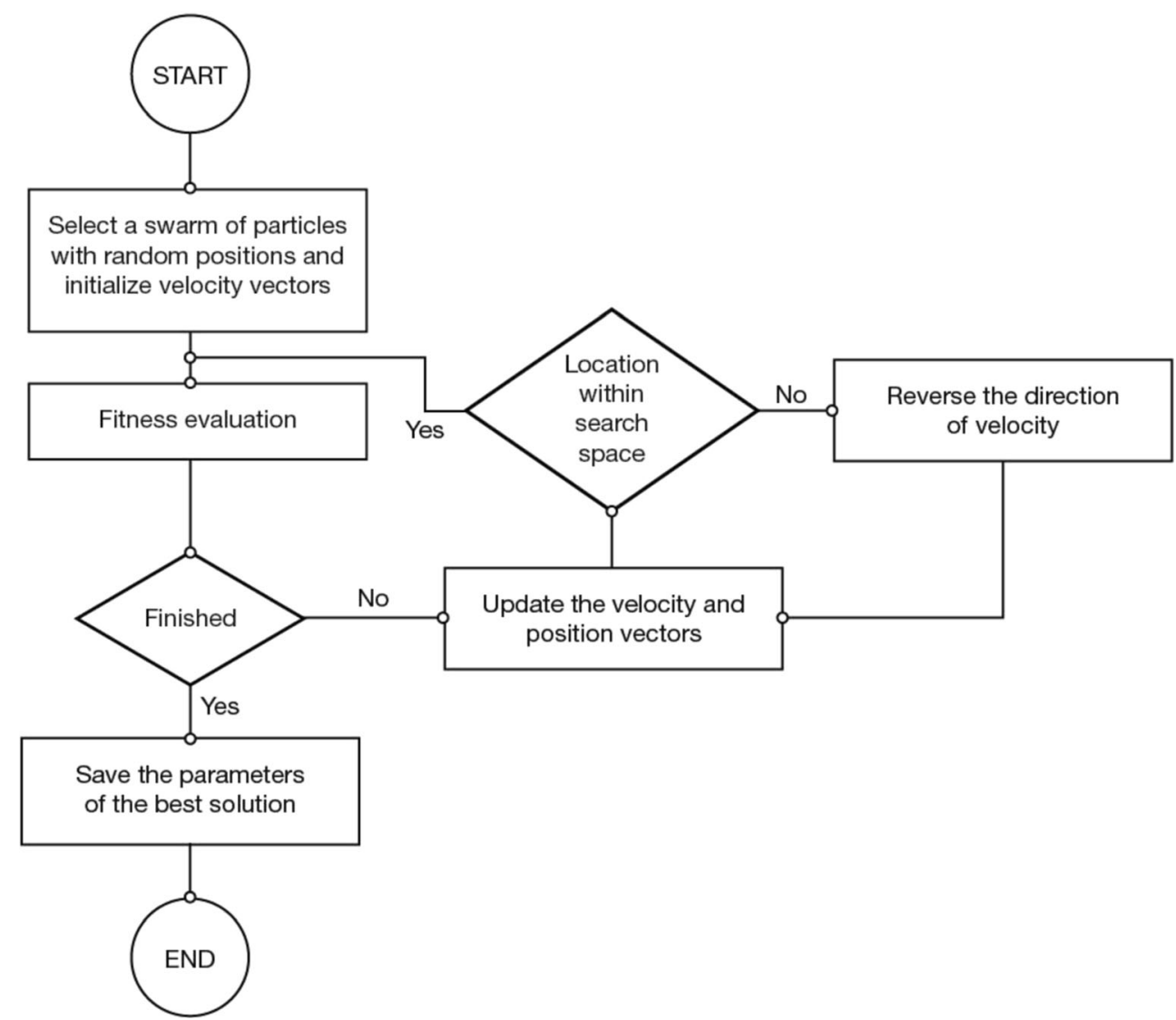

digestion modelling due to variation of characteristic and composition of feed to the anaerobic digestion process. Moreover, PSO shows great control of balance during the search of local and global solution which is indicated during convergence besides having a relatively competent search ability.

But, as every particle is moving in a random direction, population of particles has a tendency to cluster together. Hence, further hybridization between genetic algorithm and PSO is proposed for enhancement of performance before the incorporation of PSO into other artificial intelligence such as recurrent fuzzy and recurrent neural network [91].

\section{Hybrid Meta-heuristics}

In order to further improve the process control models developed, combination and coupling of models have been proposed and implemented in order to complement the disadvantage and drawbacks of individual meta-heuristic models as shown in Table 4. Hybrid meta-heuristics combines two or more other meta-heuristics to solve the same problem. The meta-heuristics can be either combined or switched one after the other over the course of the meta-heuristic. The hybridization is done to combine the desired features of each metaheuristics in order to improve the convergence speed or quality of the solution from the hybridized meta-heuristics. Since the three main models discuss earlier are fuzzy logic, ANN, and PSO, coupling of meta-heuristic models will be focused on these three.

First is the combination of fuzzy logic and ANN as shown in Fig. 3. These two models can be combined to form two different hybrid models, namely cooperative fuzzy neural network and hybrid fuzzy neural network. Fuzzy logic and ANN complements each other as the downside of fuzzy logic includes the lack of systematic method for the conversion of experience and knowledge in the form of if-then rules to be entered into the system as the basis for the prediction

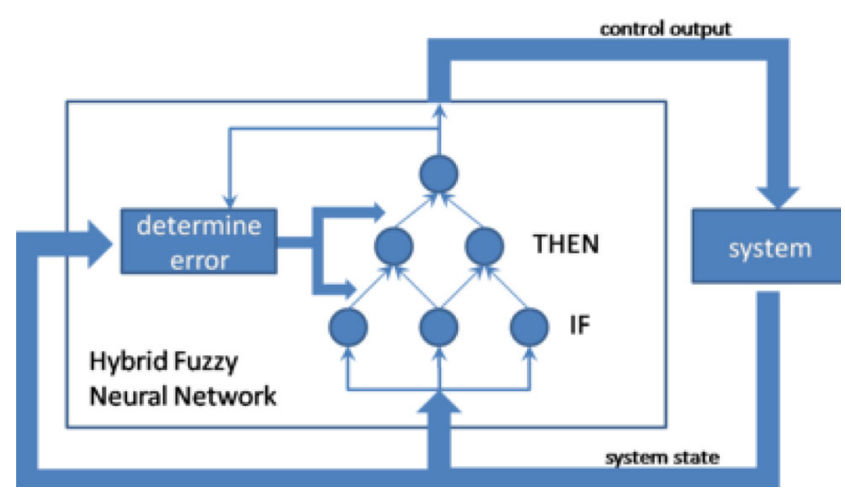

Fig. 3 Hybrid fuzzy neural network [95] 
model to determine the outputs. Besides, to ensure that the results produced are within the acceptable error range, adaptability of fuzzy logic has to be raised which can be in the form of the addition of learning algorithm. ANN in contrast is subjected to the drawback of difficulty in extraction of knowledge attained either from the configuration or weights of ANN. By grouping these two methods together, a control system of faster convergence rate and of higher robustness can be developed [96].

For cooperative fuzzy neural network, fuzzy logic and ANN work independently whereby parameters acquired from fuzzy logic are learnt by ANN. There are four main categories of cooperative fuzzy neural network which are indicated in Table 5.

Hybrid fuzzy neural network on the other hand resembles ANN where communications between fuzzy logic and ANN are no longer necessary as they are considered as a whole unit. Rules of fuzzy logic are taken to be the network, membership function as weights, whereas input and output variables are taken to be neurons. This hybrid model allows the full complementation of drawbacks which exist in individual models. With the fusing of neural network with fuzzy logic, it allows optimization of membership functions in fuzzy logic via generalization of data.

Another possible fusion is the combination of ANN with PSO where the process is summarized as shown in Fig. 4. Since ANN is heavily dependent on training process and accuracy of model developed is mainly caused by lack in training process, PSO is suggested for weight training as an alternative to use of fuzzy logic. The other reason which contributes to the favoritism of PSO to be coupled with ANN is to acquire faster convergence so that speed of process can be heightened especially for multilayer feedforward network [93]. Initially, PSO will be used to determine the best solution inside the "search" space [91]. The search space is the boundary where the inputs are randomly distributed according to initial condition. Best solution will be first searched from within the boundary prior to further search in accordance to the boundary set, while ANN is used to initiate a suitable population size where ANN weight is represented by each particle. Continuous iteration is performed until the stopping criterion is fulfilled, global solution is attained, and prediction of network is the output results wanted. New ANN function will be decided based on updated particle weights, and process is only completed when the error standard is satisfied by the trained ANN function. Summary of the process is as shown in Fig. 3.

At present, application of hybrid meta-heuristics in both modelling and control of anaerobic digestion is promising. This is due to the fact that high process stability and great reactor performance are observed when fuzzy neural network is applied to the anaerobic system. For future work, further optimization and fine tuning of fuzzy neural network can be achieved such as introduction of adaptive controllers which will be described in detailed in "Process Control of Anaerobic Digester." Examples of hybrid PSO with ANN can be found in works presented by Juang and Manshad [91, 93] which shows a reduction in absolute relative errors as compared to the use of other models. Other hybrid meta-heuristics in anaerobic digestion can be found in works presented by Tay and Zhang [97], Abu Qdais et al. [98], and Rajagopal and Radha [99].

Tay and Zhang [97] proposed the combination of ANN and fuzzy logic to determine the response of high-rate anaerobic digester $1 \mathrm{~h}$ in advance on FBR, anaerobic filter, and UASB. Abu Qdais et al. [98] predicted the methane production using multi-layer ANN and GA by considering the effect of temperature, total solids, total volatile solids, and $\mathrm{pH}$ on the biogas yield.

Rajagopal and Radha [99] developed adaptive neuro-fuzzy inference system (ANFIS) and PSO with spectral projected gradient (SPG2) algorithm to determine the effluent COD of a full-scale anaerobic wastewater treatment plant. These works demonstrated the applicability of hybrid metaheuristic approach. Combining desired features of each meta-heuristics can improve the convergence speed and quality of the solution. However, doing so requires in-depth knowledge and experience. If both algorithms are distinctly different, the tuning of parameters involved has to be carefully adjusted; else, it may trap in the local optimal solution and delay the convergence speed.

In conformity with the two hybrid models discussed earlier, it can be deduced that suitability of the application of a model is highly dependent on the control system to be modelled and controlling parameters which are to be taken into studies. As anaerobic digestion is highly sensitive and a suitable model has yet to be developed, ANN and fuzzy logic is proposed where fine tuning and further improvements are proposed to be attainable by the implementation of hybrid models. But, all these have yet to be confirmed. Hence, more work and research on this area and practical application should be tested in order to verify the proposal.

\section{Improvements Towards Wastewater Treatment System Through Introduction of Mechanistic and Meta-heuristic Models}

Based on the models discussed in "Mechanistic Models" and "Meta-Heuristic Models," it can be inferred that improvements towards implementation on industrial wastewater treatment can be observed in the form of improved prediction. For mechanistic model, improvements are observed via the inclusion of physiochemical and biochemical reaction that occurs during anaerobic digestion through the introduction of ADM1. This allows better prediction as reactions occurring within 
Table 5 Types of cooperative fuzzy neural networks [95]

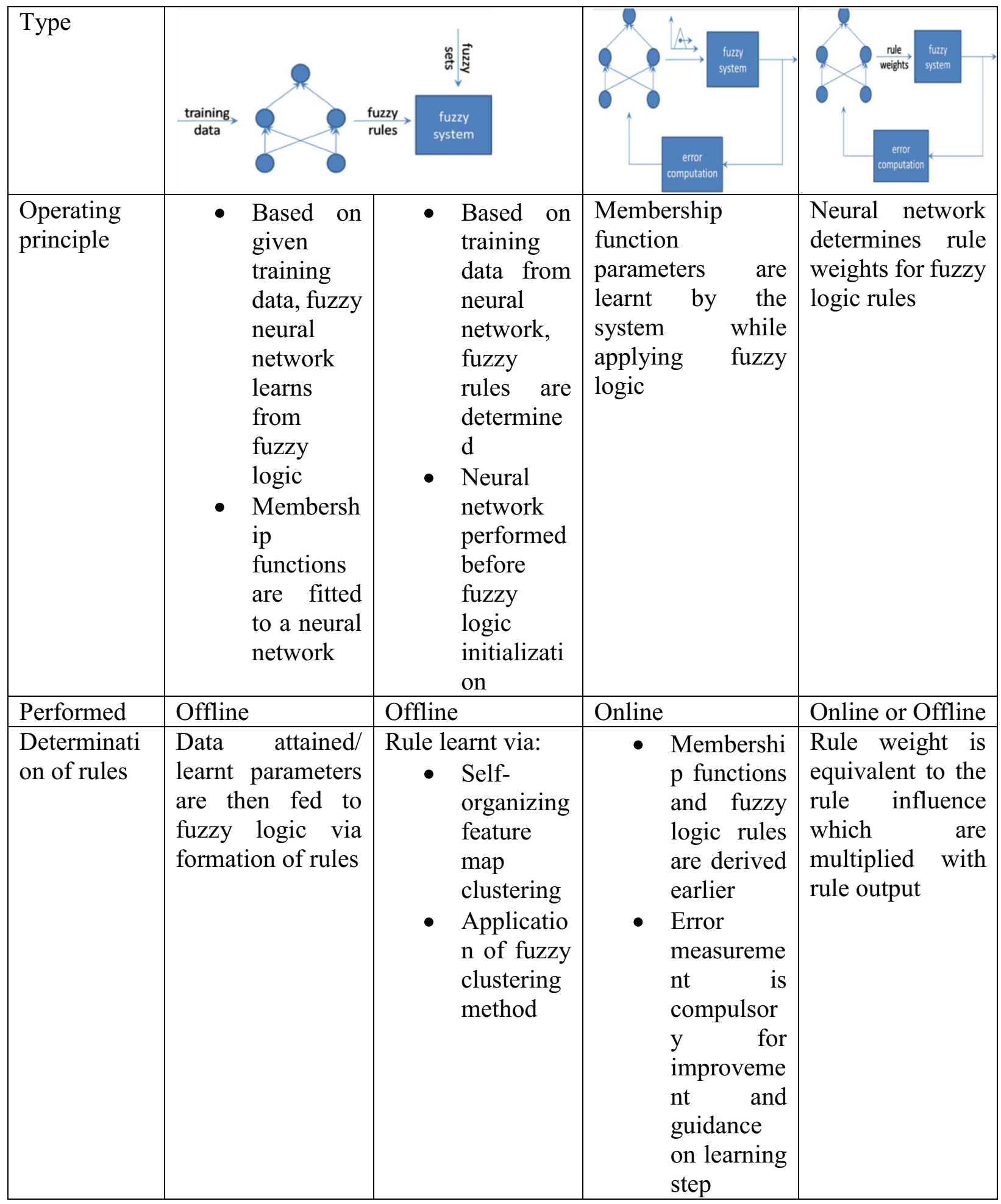

the reactor are accounted for. On the other hand, plus point for the mass balance model would be the fact that everything entering and leaving the reactor are taken into consideration, allowing improved deduction based on mass balance equations. The mass balance model allows for optimization to be performed as the influence of each parameter in and out is 


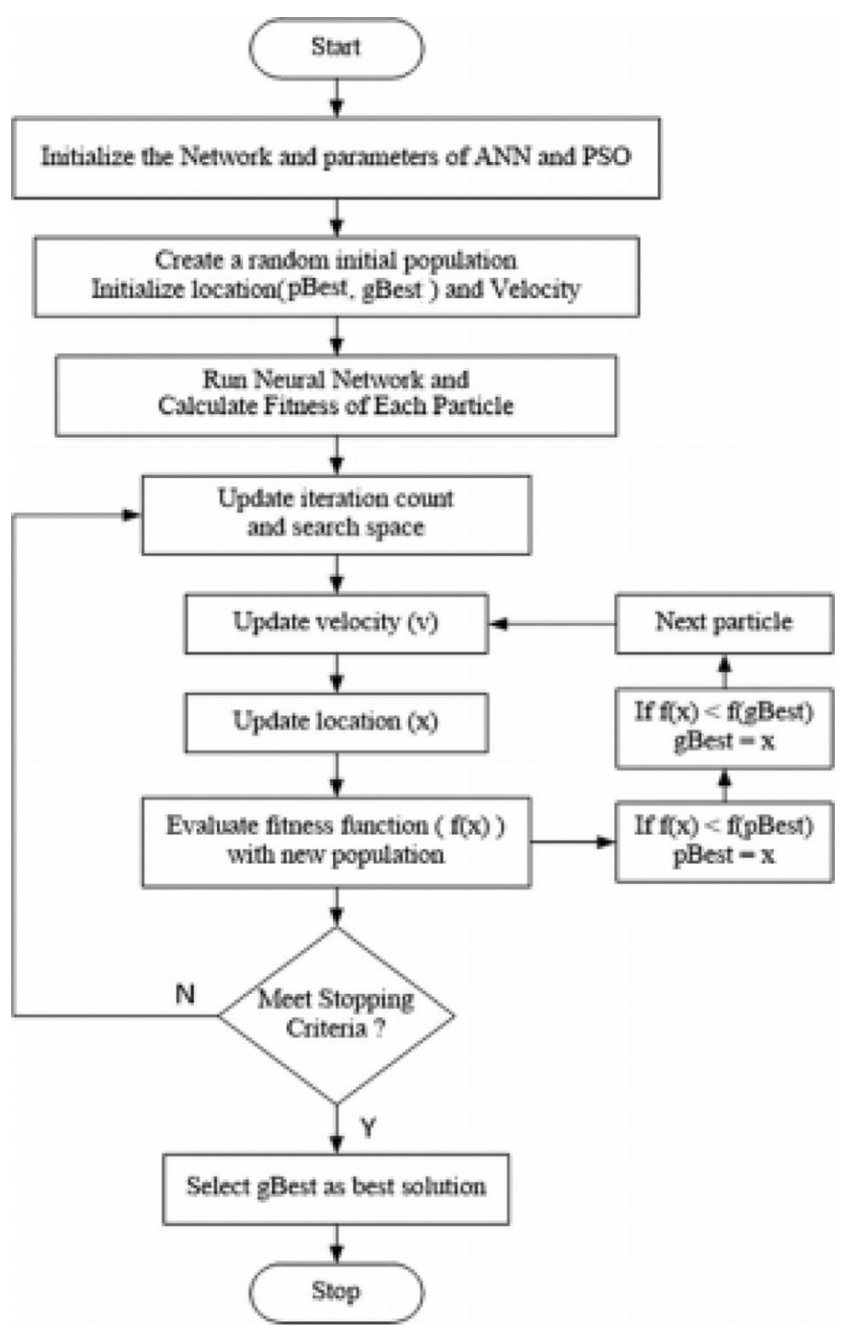

Fig. 4 Summary of the hybrid ANN and PSO process [93]

known. Therefore, it reduces the dependence of AD performance on the number of microbial consortia or unsteadiness of the system which leads to destabilization.

In terms of meta-heuristic models, better control on process parameters can be viewed through study of patterns of the system which allows earlier prediction on how the reactor would performed. This allows proper adjustment to be made for optimization of wastewater treatment process. Besides, ANN is able to study and learn the patterns of the system via the information feed to the model which would further improve the overall system performance. The challenges to be overcome include the need for in-depth understanding including characterization and experimental studies via pilot scale plant. But, in overall, it can be deduced that the implementation of mechanistic and meta-heuristics models allows improved control as parameters or condition that causes failure of system can be detected and corrected beforehand. Hence, destabilization of anaerobic digestion that would lead to system failures can be avoided/minimized.

\section{Process Control of Anaerobic Digester}

Despite its significance in anaerobic wastewater treatment, little attention has been paid over the years to compare the use of various control strategies. One of the first surveys was done by Heinzle et al. [100] with 15 control applications were referenced in this article and six of them were done in simulations (without any experimental validation). In recent years, development and improvement of bioreactor controllers have demonstrated that bioprocesses can be optimized and controlled efficiently. However, process control of anaerobic digester is still difficult and intrinsically unstable. Following are the factors typically considered when designing a controller for anaerobic digester $[58,79]$ :

- Nonlinear nature of the process

- Modelling errors induced by its complicated kinetics

- Load disturbances in the inlet composition

- Constraints in the control input due to practical operation conditions or restrictions in the actuators

The main purpose of anaerobic digester is the complete digestion of the influent to carbon dioxide and methane and/or reduction of COD level of the effluent. Therefore, its control objective(s) also departs from the same notion and varies according to the nature of its application. In wastewater treatment plant, anaerobic digester is commonly used to maintain output flow pollution level below a certain value [101].

Several control strategies have been proposed and implemented. These control strategies can be generalized into two main categories. The first category uses mechanistic model to develop a control mechanism for anaerobic digester and consists of PID-like controllers and adaptive controllers. The second category uses meta-heuristic model(s) and consists of control mechanism that uses one or more meta-heuristics to achieve the predetermined control objectives. A list of control strategies used in anaerobic digesters for wastewater treatment is displayed in Table 6 where further discussions on individual controller types can be found in the subsections below.

\section{PID-Like Controllers}

These controllers are commonly used to achieve substrate regulation. They are easier to be developed and can be implemented in wide-plant level [112]. PID-like controllers are dominant in the process industry and probably will remain so for a long time. There are several reasons that support the 
Table 6 Control strategies used in anaerobic digesters for wastewater treatment group in accordance to control method

\begin{tabular}{|c|c|c|c|c|c|}
\hline \multirow[t]{2}{*}{ Control method } & \multirow[t]{2}{*}{ Authors } & \multirow[t]{2}{*}{ Year } & \multirow[t]{2}{*}{ Model/data } & \multicolumn{2}{|l|}{ Variable } \\
\hline & & & & Controlled & Manipulated \\
\hline \multirow[t]{15}{*}{ Adaptive controller } & Hilgert et al. [102] & 2000 & Experimental data & Biogas flow rate & Influent flow rate \\
\hline & Alcaraz-González et al. [103] & 2000 & Mass balance model [53] & COD and VFA & Dilution rate \\
\hline & Alcaraz-Gonzalez et al. [104] & 2001 & Mass balance model [53] & COD & Dilution rate \\
\hline & Antonelli et al. [105] & 2003 & Mass balance model [53] & Methane gas flow rate & Dilution rate \\
\hline & Seok [106] & 2003 & Seok's model (2001) & $\begin{array}{l}\text { Propionate } \\
\quad \text { concentration }\end{array}$ & Dilution rate \\
\hline & Mailleret et al. [107] & 2004 & $\begin{array}{l}\text { Bailey and Ollis's model } \\
\text { (1986) }\end{array}$ & $\begin{array}{r}\text { Outlet pollutant } \\
\text { concentration }\end{array}$ & $\begin{array}{l}\text { Influent pollutant } \\
\text { concentration }\end{array}$ \\
\hline & Alcaraz-Gonzalez et al. [56] & 2005 & Mass balance model [53] & COD & Dilution rate \\
\hline & Mendez-Acosta et al. [58] & 2007 & Mass balance model [53] & TOC and VFA & Influent flow rate \\
\hline & Garcia-Sandoval et al. [108] & 2008 & Mass balance model [53] & COD & Dilution rate \\
\hline & Rincon et al. [59] & 2009 & Mass balance model [53] & VFA concentration & Dilution rate (flow rate) \\
\hline & Mendez-Acosta et al. [61] & 2010 & Mass balance model [53] & VFA and TA & Influent flow rate \\
\hline & Mendez-Acosta et al. [109] & 2011 & Mass balance model [53] & COD & Dilution rate \\
\hline & Rincon et al. [60] & 2012 & Mass balance model [53] & VFA and TA & $\begin{array}{l}\text { Influent VFA and COD } \\
\text { concentrations }\end{array}$ \\
\hline & Flores-Estrella et al. [5] & 2013 & Mass balance model [53] & COD & Dilution rate \\
\hline & Petre and Selisteanu [110] & 2013 & ADM-1 & COD & Dilution rate \\
\hline \multirow{2}{*}{$\begin{array}{l}\text { Proportional-integral- } \\
\text { derivative (PID)-like } \\
\text { controller }\end{array}$} & Harmand et al. [111] & 2000 & $\begin{array}{l}\text { Linear model (experimental } \\
\text { data) }\end{array}$ & Gas flow rate & Influent flow rate \\
\hline & Alvarez-Ramirez et al. [112] & 2002 & Pavlostathis et al. model [51] & COD & Dilution rate \\
\hline $\begin{array}{l}\text { Proportional-integral }(\mathrm{PI}) \\
\text { controller }\end{array}$ & Alvarez-Ramirez et al. [112] & 2002 & Pavlostathis et al. model [51] & COD & Dilution rate \\
\hline Output feedback control & Mendez-Acosta et al. [113] & 2008 & Mass balance model [53] & VFA concentration & Dilution rate \\
\hline $\begin{array}{l}\text { Multi-objective cascade } \\
\text { controller }\end{array}$ & García-Diégueza et al. [69] & 2011 & ADM-1 & $\begin{array}{l}\text { Methane flow rate, } \\
\text { VFA }\end{array}$ & COD concentration \\
\hline \multirow[t]{3}{*}{ Fuzzy controller } & Polit et al. [114] & 2002 & Denac et al. model [52] & Gas flow rate & Influent flow rate \\
\hline & Punal et al. [115] & 2003 & Experimental data & VFA & Influent flow rate \\
\hline & Yordanova [116] & 2004 & Mass balance model [53] & $\begin{array}{l}\text { Biogas output flow rate } \\
\text { and } \mathrm{pH}\end{array}$ & Dilution rate \\
\hline $\begin{array}{l}\text { Linear control with } \\
\text { feedforward/feedback } \\
\text { structure }\end{array}$ & Mendez-Acosta et al. [117] & 2005 & Mass balance model [53] & COD of output & Inlet COD concentration \\
\hline
\end{tabular}

use of these controllers. Among them are their long history of proven operation, well understood by operational staffs, and have automatic and manual switching, set point tracking, and emergency manual modes.

Despite their wide adoptions in the industry, the performances of PID-like controllers have several limitations. One of the limitations is the narrow range of the operating conditions [102]. Moreover, the cost of implementation can increase due to the number of instrumentations and only restricted operation can be assured. PID-like controllers also have difficulty in considering various parameters that influence and characterize the growth of microorganisms [78], and they neglect the nonlinearities inherent in most biological processes [105]. Lastly, this method is susceptible to disturbances in the input variable(s) and significant set point changes $[61,112]$. Due to these limitations, PID-like controllers are becoming obsolete - with three papers proposing PID controllers in a decade ago (Table 6) and none in recent years.

\section{Adaptive Controllers}

Adaptive controllers were designed and developed to address limitations posed by PID-like controllers. Unlike the former approaches, adaptive controllers consider the nonlinearity and nonstationary features of the anaerobic digestion processes $[55,118,119]$. These controllers are typically derived from a physical model of the digester (mass balance model or ADM1 ), and they also feature an online estimation of physically related unknown variables and parameters [53]. The online 
estimators or observers commonly used in biological processes include asymptotic observers [110], disturbance decoupled observer [120], Luenberger observer [58, 61], state observer [60], and interval observer [76]. Despite their reported satisfactory results, these observers require the total knowledge of the process variables, which are rarely available in practice. If the whole system does not have the details of these variables, it will become nonobservable and consequently rendering it impossible to design online estimators. This limitation has prevented the wide adoptions of the observer schemes and the nonlinear controllers at the industrial scale.

Nevertheless, adaptive controller offers its own merits and demerits compared to the conventional PID-like controllers. One of the merits of this approach is its variation of the model parameters, which allow it to have good disturbance rejection capability $[102,121]$. It is also able to handle actuator constraints and provides soft control actions while handling process nonlinearities [105]. Lastly, it is able provide online estimation of several unknown variables and parameters, allowing adaptive controllers to only require simple sensors to work with [79]. The main disadvantage of this approach is its complexity. As mentioned earlier, anaerobic digestion is complex and nonlinear; hence, they are difficult to model. Moreover, it also requires linear parameterization to implement parameter estimator [101], which typically obtained by putting together a large set of kinetic and yield parameters. Therefore, the use of adaptive controllers might not be suitable for anaerobic digestion of complex wastewater, where the kinetics and yield parameters of these processes are not readily available.

\section{Meta-heuristic-Based Controllers}

Meta-heuristics are not only used to model anaerobic digester but they are also used as basis to minimize the pollution level of the treated wastewater and to control biogas production rate [122]. However, among all meta-heuristics, only fuzzy controllers were found controlling certain output variables of anaerobic digesters $[115,116]$.

Punal et al. [115] developed set of rules (control law) based on Mamdani's fuzzy inference method to handle VFA concentration of anaerobic digester. These rules were developed based on the acquired knowledge from the process. Variables used are the input flow rate of the raw wastewater, while the output was the degree of modification required for the influent flow rate in order to lead the system to achieve the desired set point.

Yordanova et al. [116] developed a two-stage fuzzy logic to control biogas production rate of an anaerobic digester with controlled variable to be the production rate of biogas and manipulated variable to be the dilution rate. Validation was performed through PI controller construction. This comparison demonstrated the effectiveness of fuzzy logic-based controller in providing faster responses to reference changes and disturbances with less overshoot.

\section{Identified Gaps and Suggestions for Improvements}

Despite its wide adoption, anaerobic digestion is difficult to model, especially when the biological systems are generally ill-defined [116]. Moreover, the reproducibility of the experiment is low as the microbial activity is highly dependent on the physiological state of the microorganisms and its environment, especially in case of mixed cultures where interaction between different microorganisms is fairly complex. This is also hindered by the lack of available measurements to monitor the activity of microorganisms. Moreover, the experiment data tend to be noisy and the characteristics of the noise are difficult to define. Systematic errors may also present and accumulate since anaerobic digestion processes occur sequentially.

These issues pose several challenges in controlling anaerobic digester. Despite the different control strategies that have been applied in the face of incomplete system knowledge, the task of designing a control law to ensure robustness against load disturbances and parameter variations is, in general, still difficult. Wen and Vassiliadis [85] and Boger [123] characterized the ability to monitor and control the effluent from wastewater treatment process as "primitive" and "notoriously difficult." Lindberg [124] further defined wastewater treatment to be a complex multivariate process with highly variable inputs, nonlinear time varying dynamics, and a time series structure with autocorrelation that is subject to large disturbances.

Nevertheless, there were several success stories in monitoring and controlling anaerobic digesters. Among them are works reported by Harmand et al. [111], Seok [106], Mailleret et al. [107], Mendez-Acosta et al. [58], and Garcia-Dieguez et al. [69]. Harmand et al. [111] proposed disturbance accommodating controller to fluidized-bed anaerobic digester. This method is not only robust to large internal and external disturbances, but it is also robust to expected and unexpected disturbances. Seok's [106] controller has been tested on an anaerobic fluidized-bed bioreactor for $200 \mathrm{~h}$. Despite sudden increase in the feed concentration of up to $50 \%$, this method can maintain the propionate concentration at $700 \mathrm{mg} \mathrm{H} \mathrm{Prl}^{-1}$. MendezAcosta et al. [58] implemented and validated robust-adaptive controller to regulate VFA in an upflow fixed-bed reactor of an anaerobic digester for 36 days under different set point values and different scenarios. Their methods successfully demonstrated the use of an observer to control VFA even in the presence of noisy measurements and control input saturations. Garcia-Dieguez et al. [69] implemented multi-objective cascade controller based on VFA concentration in the effluent and methane production rate in an upflow sludge bed filter (USBF) reactor (anaerobic treatment of winery wastewater) 
There were also several control schemes that performed well in their simulation studies such as the Rincon et al. method [60] that can handle the uncertainty in the kinetic function, biomass concentration, biological yield coefficients, kinetic parameters, and the effect of input saturation. Petre and Selisteanu's [110] robust-adaptive control strategy can be combined with a state asymptotic observer or an internal observer and a parameter estimator to estimate unknown kinetics of the process online and withstand disturbances and noisy data acting on the process and more importantly uncertainties in the growth rate and influent substrate concentration [76].

Nevertheless, there still remains several technical challenges: (1) Can their proposed control method be applied on different types of anaerobic reactors, e.g., UASB, UASFF, and UASB-HCPB?; (2) Since most of the water treatment plants handle large effluent, is there proposed method scalable to different scales of water treatment plants?; (3) Can their method handle different types of effluents, e.g., POME, pulp and paper mill effluent, and olive mill effluent?

Use of meta-heuristics in anaerobic digestion suffers similar drawbacks. The published articles implemented metaheuristics for specific problems, where the problems size, inputs, and outputs are fixed. There is no clear evidence that demonstrates how the meta-heuristics used can be scaled up well for larger settings. Nevertheless, there are other potentials in meta-heuristics that have yet been explored. For example, genetic algorithm (GA) has various variables that can influence the anaerobic digester and lead to better prediction and control. These variables include crossover probability, mutation probability, elite preservation, selection, population size, and generation size. There are also more opportunities in implementing more sophisticated meta-heuristics such as ant colony optimization (ACO), simulated annealing (SA), tabu search (TS), artificial bee colony algorithm (ABC), cuckoo search (CS), charge system search (CSS), glowworm swarm optimization (GSO), and firefly algorithm (FFA). In-depth studies have to be performed in order to determine the best controller to be applied for a particular system where further optimization can be done to achieve best performance.

The use of anaerobic digestion systems in wastewater treatment is growing immensely in Southeast Asian countries. This is due to the increasing production of palm oil especially in Malaysia and Indonesia, which are the largest crude palm oil-producing countries. Chin et al. [3] have projected that an estimated 3.2 million MWh of electricity, equivalent to the electricity consumption by 700,000 households, can be generated from the treatment of POME generated in Malaysia in 2011. The investment of palm oil mills on high-rate anaerobic digesters could potentially generate immense profits, overturning the conventional image of wastewater treatment in process plants that used to be just a part of the process to comply with government regulations. Thus, it is vital to devise and develop the right model and a robust controller that can suit anaerobic digestion of different wastewaters to ensure consistent production of biogas.

Though anaerobic digestion is an established method for wastewater treatment, the current anaerobic digestion technology is also evolving to anaerobic co-digestion (treatment of different wastes in a single reactor) $[35,125]$ and temperaturephased anaerobic digestion system $[38,126]$ to boost reactor performance and biogas production. These technologies offer more opportunities to improve the performance of anaerobic digester in reducing pollution level of the treated wastewater and increasing the biogas production rate. Nevertheless, the advancement of anaerobic digestion technology also implies that the control of the anaerobic digester system will become more complicated as the number of manipulated variables increases.

\section{Conclusion}

Anaerobic digester is commonly used to treat wastewater with high organic carbon content, as an alternative to aerobic digestion. However, the sensitivity of anaerobic digester has proven to be a challenge in controlling its desired output(s): treated wastewater with lower organic carbon content and/or high biogas production rate. Till to date, this challenge still persists together with scalability of the anaerobic digester and variation in the feed characteristics throughout the year. With the advancement of nonlinear approaches, meta-heuristics, and their combinations, there are plenty of rooms for further improvements for both anaerobic digester models and controllers. More importantly, increasing production of palm oil and economic benefits can drive greater adoption of anaerobic digester in palm oil mills, especially in Southeast Asian countries. With this comprehensive review, it is clear that adaptive controllers provide a wider option in terms of controlled and manipulated variable for wastewater treatment plants. However, because of the varied nature of parameters that affect the various operating conditions in wastewater treatment plants, it is necessary for an in-depth study to understand the particular system before determining a suitable adaptive controller.

\section{References}

1. Escudié R, Cresson R, Delgenès JP, Bernet N (2011) Control of start-up and operation of anaerobic biofilm reactors: an overview of 15 years of research. Water Res 45:1-10

2. Chen Y, Cheng JJ, Creamer KS (2008) Inhibition of anaerobic digestion process: a review. Bioresour Technol 99:4044-4064

3. Chin MJ, Poh PE, Tey BT, Chan ES, Chin KL (2013) Biogas from palm oil mill effluent (POME): opportunities and challenges from Malaysia's perspective. Renew Sust Energ Rev 26:717-726 
4. Seghezzo L, Zeeman G, van Lier JB, Hamelers HVM, Lettinga G (1998) A review: the anaerobic treatment of sewage in UASB and EGSB reactors. Bioresour Technol 65:175-190

5. Flores-Estrella R, Quiroz G, Mendez-Acosta HO, Femat RH (2013) Control of anaerobic digester for winery industry wastewater treatment. Ind Eng Chem Res 52:2625-2632

6. Jensen JK, Jensen AB (2000) Biogas and natural gas fuel mixture for the future. 1st World Conference and Exhibition on Biomass for Energy and Industry, Sevilla, Spain

7. Batstone DJ, Puyol D, Flores-Alsina X, Rodriguez J (2015) Mathematical modelling of anaerobic digestion processes: applications and future needs. Rev Environ Sci Biotechnol 14(4):595613

8. Donoso-Bravo A, Mailier J, Martin C, Rodriguez J, Aceves-Lara CA, Wouwer AV (2011) Model selection, identification and validation in anaerobic digestion: a review. Water Res 45:5347-5364

9. Kythreotou N, Florides G, Tassou SA (2014) A review of simple to scientific models for anaerobic digestion. Renew Energy 71: 701-714

10. Gerardi MH (2003) The microbiology of anaerobic digesters. Wiley-Interscience, New Jersey 51-57

11. Gerardi MH (2006) Wastewater bacteria. Wiley-Interscience, New Jersey 19-31

12. Poh PE, Chong MF (2009) Development of anaerobic digestion methods for palm oil mill effluent (POME) treatment. Bioresour Technol 100:1-9

13. van Haandel A, Kato MT, Cavalcanti PFF, Florencio L (2006) Anaerobic reactor design concepts for the treatment of domestic wastewater. Rev Environ Sci Biotechnol 5:21-38

14. Lettinga $\mathrm{G}$ et al (1984) High-rate anaerobic waste-water treatment using the UASB reactor under a wide range of temperature conditions. Biotechnol Genet Eng Rev 2:253-283

15. Kim W, Cho K, Lee S, Hwang S (2013) Comparison of methanogenic community structure and anaerobic process performance treating swine wastewater between pilot and optimized lab scale bioreactors. Bioresour Technol 145:48-56

16. Tong SL, Jaafar AB (2006) POME biogas capture, upgrading and utilization. Palm Oil Eng Bull 78:11-17

17. Ugoji EO (1997) Anaerobic digestion of palm oil mill effluent and its utilization as fertilizer for environmental protection. Renew Energy 10:291-294

18. Halalsheh M et al (2005) Effect of SRT and temperature on biological conversions and the related scum-forming potential. Water Res 39:2475-2482

19. Kalyuzhnyi SV et al (1996) Organic removal and microbiological features of UASB-reactor under various organic loading rates. Bioresour Technol 55:47-54

20. Lettinga G (1995) Anaerobic digestion and wastewater treatment systems. Antonie Van Leeuwenhoek 67:3-28

21. Giraldo-Gomez E and Duque M (1998) Automatic start-up of a high rate anaerobic reactor using a fuzzy logic control system. Fifth Latin American Workshop-Seminar Wastewater Anaerobic Treatment, 27th-30th, Vina del Mar, Chile

22. Ji JY, Xing YJ, Ma ZT, Zhang M, Zheng P (2013) Acute toxicity of pharmaceutical wastewaters containing antibiotics to anaerobic digestion treatment. Chemosphere 91:1094-1098

23. Sampaio MA, Gonçalves MF, Marques IP (2011) Anaerobic digestion challenge of raw olive mill wastewater. Bioresour Technol 102:10810-10818

24. Wang W, Ma W, Han H, Li H, Yuan M (2011) Thermophilic anaerobic digestion of Lurgi coal gasification wastewater in a UASB reactor. Bioresour Technol 102:2441-2447

25. Cao W, Mehrvar M (2011) Slaughterhouse wastewater treatment by combined anaerobic baffled reactor and $\mathrm{UV} / \mathrm{H}_{2} \mathrm{O}_{2}$ processes. Chem Eng Res Des 89(7):1136-1143
26. Rajakumar R, Meenambal T, Rajesh Banu J, Yeom LT (2011) Treatment of poultry slaughterhouse wastewater in upflow anaerobic filter under low upflow velocity. Int J Environ Sci Technol 8(1):149-158

27. Mittal GS (2004) Characterization of the effluent wastewater from abattoirs for land application. Food Rev Int 20(3):229-256

28. Caldera Y, Madueno P, Griborio A, Fernandez N, Gutierrez E (2005) Effect of the organic load in the performance of the UASB reactor treating slaughterhouse effluent. Revista Tecnica de la Facultad de Ingenieria Universidad del Zulia 28(2):119-127

29. Lopez RJ, Higgins SR, Pagaling E, Yan T, Cooney MJ (2014) High rate anaerobic digestion of wastewater separated from grease trap waste. Renew Energy 62:234-242

30. Sànchez E, Borja R, Tavieso L, Martín A, Colmenarejo MF (2005) Effect of organic loading rate on the stability, operational parameters and performance of a secondary upflow anaerobic sludge bed reactor treating piggery waste. Bioresour Technol 96:335-344

31. Sreekanth D, Sivaramakrishna D, Himabindu V, Anjaneyulu Y (2009) Thermophilic treatment of bulk drug pharmaceutical industrial wastewaters by using hybrid up flow anaerobic sludge blanket reactor. Bioresour Technol 100:2534-2539

32. Alvarado-Lassman A et al (2008) Brewery wastewater treatment using anaerobic inverse fluidized bed reactors. Bioresour Technol 99:3009-3015

33. Raposo F, Borja R, Sanchez E, Martin MA, Martin A (2004) Performance and kinetic evaluation of the anaerobic digestion of two-phase olive mill effluents in reactors with suspended and immobilized biomass. Water Res 38(8):2017-2026

34. Poh PE, Chong MF (2014) Upflow anaerobic sludge blankethollow centered packed bed (UASB-HCPB) reactor for thermophilic palm oil mill effluent (POME) treatment. Biomass Bioenergy 67:231-242

35. Najafpour GD, Zinatizadeh AAL, Mohamed AL, Hasnain Isa M, Nasrollahzadeh H (2006) High-rate anaerobic digestion of palm oil mill effluent in an upflow anaerobic sludge-fixed film bioreactor. Process Biochem 41:370-379

36. Fang C, O-Thong S, Boe K, Angelidaki I (2011) Comparison of UASB and EGSB reactors performance, for treatment of raw and deoiled palm oil mill effluent (POME). J Hazard Mater 189:229 234

37. Long JH, Aziz TN, de los Reyes FL III, Ducoste JJ (2012) Anaerobic co-digestion of fat, oil, and grease (FOG): a review of gas production and process limitations. Process Saf Environ Prot 90:231-245

38. Ke S, Shi Z, Fang HHP (2005) Application of two-phase anaerobic degradation in industrial wastewater treatment. Int J Environ Pollut 23:65-80

39. Kim JK, Oh BR, Chun YN, Kim SW (2006) Effects of temperature and hydraulic retention time on anaerobic digestion of food waste. J Biosci Bioeng 102:328-332

40. Yilmaz T, Yuceer A, Basibuyuk M (2008) A comparison of the performance of mesophilic and thermophilic anaerobic filters treating papermill wastewater. Bioresour Technol 99:156-163

41. Yu HQ, Fang HHP, Gu GW (2002) Comparative performance of mesophilic and thermophilic acidogenic upflow reactors. Process Biochem 38:447-454

42. Muller A, Marsili-Libelli S, Aivasidis A, Lloyd T, Kroner S, Wandrey C (1997) Fuzzy control of disturbances in a wastewater treatment plant. Water Res 31(12):3157-3167

43. Lau I, Fang H (1997) Effect of temperature shock to thermophilic granules. Water Res 31:2626-2632

44. Parawira W, Murto M, Zvauya R, Mattiasson B (2006) Comparative performance of a UASB reactor and an anaerobic packed-bed reactor when treating potato waste leachate. Renew Energy 31:893-903 
45. Altas L (2009) Inhibitory effect of heavy metals on methaneproducing anaerobic granular sludge. J Hazard Mater 162:15511556

46. Leighton IR, Forster CF (1998) The effect of heavy metals on a thermophilic methanogenic upflow sludge blanket reactor. Bioresour Technol 63:131-137

47. Lin CY, Chen CC (1999) Effect of heavy metals on the methanogenic UASB granule. Water Res 33(2):409-416

48. Chen JL, Ortiz R, Steele TWJ, Stuckey DC (2014) Toxicants inhibiting anaerobic digestion: a review. Biotechnol Adv 32: 1523-1534

49. Patel H, Madamwar D (2002) Effects of temperatures and organic loading rates on biomethanation of acidic petrochemical wastewater using an anaerobic upflow fixed-film reactor. Bioresour Technol 82:65-71

50. Bailey J, Ollis D (1986) On-line estimation of microbial specific growth rates. Automatica 22:705-709

51. Pavlostathis SG, Gosset JM (1986) A kinetic model for anaerobic digestion of biological sludge. Biotechnol Bioeng 28:1519-1530

52. Denac M, Miguel A, Dunn I (1988) Modelling dynamic experiments on the anaerobic degradation of the molasses wastewater. Biotechnol Bioeng 31:1-10

53. Bernard O, Polit M, Hadj-Sadok Z, Pengov M, Dochain D, Estaben M, Labat P (2001) Advanced monitoring and control of anaerobic wastewater treatment plants. Water Sci Technol 43(7): 175-182

54. Batstone DJ, et al. (2002) Anaerobic Digestion Model No. 1 (ADM1). Report No. 13. London: IWA Publishing

55. Bastin G and Dochain D (1990) On-line estimation and adaptive control of bioreactors. Elsevier

56. Alcaraz-Gonzalez V et al (2005) Robust interval-based regulation for anaerobic digestion processes. Water Sci Technol 52(1-2): $449-456$

57. Dimitrova N, Krastanov M (2011) Nonlinear adaptive stabilizing control of an anaerobic digestion model with unknown kinetics. Int J Robust Nonlinear Control 22(15):1743-1752

58. Mendez-Acosta HO, Steyer JP, Femat R, Gonzalez-Alvarez V (2007) Robust nonlinear control of a pilot scale anaerobic digester. Lecture Notes Control Inform Sci 361:165-199

59. Rincon A, Angulo F, Olivar G (2009) Control of an anaerobic digester through normal form of fold bifurcation. J Process Control 19:1355-1367

60. Rincon A, Erazo C, Angulo F (2012) A robust adaptive controller for an anaerobic digester with saturated input: guarantees for the boundedness and convergence properties. J Process Control 22: 1785-1792

61. Mendez-Acosta HO, Palacios-Ruiz B, Alcaraz-Gonzalez V, Gonzalez-Alvarez V, Garcia-Sandoval JP (2010) A robust control scheme to improve the stability of anaerobic digestion processes. $\mathrm{J}$ Process Control 20:375-383

62. Ward AJ, Hobbs PJ, Holliman PJ, Jones DL (2008) Optimisation of the anaerobic digestion of agricultural resources. Bioresour Technol 99:7928-7940

63. Batstone DJ, Styer JP (2007) Use of modeling to evaluate best control practice for winery-type wastewasters. Water Sci Technol 56:147-152

64. Mu SJ, Zeng Y, Tartakovsky B, Wu P (2007) Simulation and control of an upflow anaerobic sludge blanket (UASB) reactor using an ADM1-based distributed parameter model. Ind Eng Chem Res 46:1519-1526

65. Garcia C, Molina F, Roca E, Lema JM (2007) Fuzzy-based control of an anaerobic reactor treating wastewaters containing ethanol and carbohydrates. Ind Eng Chem Res 46:6707-6715

66. Gauthier JP, Kupka I (1994) Observability and observers for nonlinear systems. SIAM J Control Opt 34(4):975-994
67. Lauwers J et al (2013) Mathematical modeling of anaerobic digestion of biomass and waste: power and limitations. Prog Energy Combust Sci 39:383-402

68. García-Diéguez C, Bernard O, Roca E (2013) Reducing the Anaerobic Digestion Model No. 1 for its application to an industrial wastewater treatment plant treating winery effluent wastewater. Bioresour Technol 132:244-253

69. Garcia-Dieguez C, Molina F, Roca E (2011) Multi-objective cascade controller for an anaerobic digester. Process Biochem 46: 900-909

70. Batstone DJ, Keller J (2003) Industrial applications of the IWA anaerobic digestion model no. 1 (ADM1). Water Sci Technol 47: 199-206

71. Mairet F, Bernard O, Ras M, Lardon L, Steyer JP (2011) Modeling anaerobic digestion of microalgae using ADM1. Bioresour Technol 102:6823-6829

72. Paredes C, Cegarra J, Roig A, Sánchez-Monedero MA, Bernal MP (1999) Characterization of olive mill wastewater (alpechin) and its sludge for agricultural purposes. Bioresour Technol 67:111-115

73. Poh PE, Yong WJ, Chong MF (2010) Palm Oil Mill Effluent (POME) characteristic and the applicability of anaerobic systems for the treatment of POME. Ind Eng Chem Res 49:11732-11740

74. Punal A, Roca E, Lema JM (2002) An expert system for monitoring and diagnosis of anaerobic wastewater treatment plants. Water Res 36:2656-2666

75. Karakuzu C, Turker M, Ozturk S (2006) Modelling, on-line state estimation and fuzzy control of production scale fed-batch baker's yeast fermentation. Control Eng Pract 14:959-974

76. Montiel-Escobar JL, Alcaraz-Gonzalez V, Mendez-Acosta HO, Gonzalez-Alvarez V (2012) ADM1-based robust interval observer for anaerobic digestion processes. Clean Soil Air Water 40(9): 933-940

77. Boscolo A, Mangiavacchi C, Drius F, Rongione F, Pavan P, Cecchi F (1993) Fuzzy control of an anaerobic digester for the treatment of the organic fraction of municipal solid waste (MSW). Water Sci Technol 27(2):57-68

78. Mingzhi H, Ma Y, Jinquan W, Yan W (2009) Simulation of a paper mill wastewater treatment using a fuzzy neural network. Exp Syst Appl 36:5064-5070

79. Steyer J, Bernard O, Batstone D, Angelidaki I (2006) Lessons learnt from 15 years of ICA in anaerobic digesters. Water Sci Technol 53(4):25-33

80. Turkdogan-Aydinol FI, Yetilmezsoy K (2010) A fuzzy-logicbased model to predict biogas and methane production rates in a pilot-scale mesophilic UASB reactor treating molasses wastewater. J Hazard Mater 182:460-471

81. Varne AL, Macwan J (2012) Fuzzy rule based approach for modelling biogas production rate in a real scale UASB reactor treating distillery wastewater. J Environ Res Dev 6(3):788-800

82. Trelea IC (2003) The particle swarm optimization algorithm: convergence analysis and parameter selection. Inf Process Lett 85: 317-325

83. Ruiz I, Veiga MC, de Santiago P, Blázquez R (1997) Treatment of slaughterhouse wastewater in a UASB reactor and an anaerobic filter. Bioresour Technol 60:251-258

84. Cai ZX (1997) Intelligent control: principles, techniques and applications. Series in Intelligent Control and Intelligent Automation: Volume 7:182-238

85. Wen CH, Vassiliadis CA (1998) Applying hybrid artificial intelligence techniques in wastewater treatment. Eng Appl Artif Intell 11(6):685-705

86. Holubar P, Zani L, Hager M, Froschl W, Radak Z, Braun R (2002) Advanced controlling of anaerobic digestion by means of hierarchical neural networks. Water Res 36:2582-2588

87. Rangasamy P, Iyer PVR, Ganesan S (2007) Anaerobic tapered fluidized bed reactor for starch wastewater treatment and 
modelling using multilayer perceptron neural network. J Environ Sci 19:1416-1423

88. Abbas N, Nasser Y, Ahmad KE (2015) Recent advances on artificial intelligence and learning techniques in cognitive radio networks. EURASIP J Wirel Commun Netw 174

89. Bai Q (2010) Analysis of particle swarm optimization algorithm. Comput Inform Sci 3(1)

90. Nguyen D, Gadhamshetty V, Nitayavardhana S, Khanal SK (2015) Automatic process control in anaerobic digestion technology: a critical review. Bioresour Technol 193:513-522

91. Juang CF (2004) A hybrid of genetic algorithm and particle swarm optimization for recurrent network design. IEEE Trans Syst Man Cybernet 34 (2)

92. Zhang Q, Li C, Liu Y, Kang L (2007) Fast multi-swarm optimization with Cauchy mutation and crossover operation. In: Advances in computation and intelligence. Springer: $344-352$.

93. Manshad AK, Rostami H, Rezaei H and Hosseini SM (2015) Application of artificial neural network-particle swarm optimization algorithm for prediction of asphaltene precipitation during gas injection process and comparison with Gaussian process algorithm. J Energy Resour Technol 137

94. Smith SA (2009) Critical evaluation of the sugar degradation pathways of Anaerobic Digestion Model No. 1. Ph.D. thesis, Washington State University

95. Kruse R (2008) Fuzzy neural network. Scholarpedia 3 (11)

96. Vieira JAB, Dias FM, Mota AM (2004) Artificial neural networks and neuro-fuzzy systems for modelling and controlling real systems: a comparative study. Eng Appl Artif Intell 17(3):265-273

97. Tay J, Zhang X (2000) A fast predicting neural fuzzy model for high-rate anaerobic wastewater treatment systems. Water Res 34(11):2849-2860

98. Abu Qdais H, Bani Hani K, Shatnawi N (2010) Modelling and optimization of biogas production from a waste digester using artificial neural network and genetic algorithm. Resour Conserv Recycl 54:359-363

99. Rajagopal V, Radha V (2013) Selection of optimum features using PSO-SPG2 for predicting COD effluent level in wastewater. Int J Eng Technol 5:3318-3327

100. Heinzle E, Dunn IJ, Ryhiner GH (1993) Modeling and control of anaerobic wastewater treatment. Adv Biochem Eng Biotechnol 48:79-114

101. Monroy O, Ramirez J, Cuervo F, Ricardo F (1996) An adaptive strategy to control anaerobic digesters for wastewater treatment. Ind Eng Chem Res 35:3442-3446

102. Hilgert N, Harmand J, Steyer J, Vila P (2000) Nonparametric identification and adaptive control of an anaerobic fluidized bed digester. Control Eng Pract 8(4):367-376

103. Alcaraz-Gonzalez V, et al. (2000) Robust interval-based SISO and SIMO regulation for a class of highly uncertain bioreactors: application to the anaerobic digestion. Proceedings of the 39th IEEE Conference on Decision and Control 2000 (Vol. 5): 4532-4537

104. Alcaraz-Gonzalez V, et al. (2001) Robust interval-based siso regulation under maximum uncertainty conditions in an anaerobic digester. Proceedings of the 2001 I.E. International Symposium on Intelligent Control 2001: 240-245

105. Antonelli R, Harmand J, Steyer JP, Astolfi A (2003) Set-point regulation of an anaerobic digestion process with bounded output feedback. IEEE Trans Control Syst 11(4):495-504

106. Seok J (2003) Hybrid adaptive optimal control of anaerobic fluidized bed bioreactor for the de-icing waste treatment. JBiotechnol 102:165-175
107. Mailleret L, Bernard O, Steyer JP (2004) Nonlinear adaptive control for bioreactors with unknown kinetics. Automatica 40:13791385

108. Garcia-Sandoval JP, Gonzalez-Alvarez V, Castillo-Toledo B, Pelayo-Ortiz C (2008) Robust discrete control of nonlinear processes: application to chemical reactors. Comput Chem Eng 32: 3246-3253

109. Mendez-Acosta HO, Garcia-Sandoval JP, Gonzalez-Alvarez V, Alcaraz-Gonzalez V, Jauregui-Jauregui JA (2011) Regulation of the organic pollution level in anaerobic digesters by using off-line COD measurements. Bioresour Technol 102:7666-7672

110. Petre E, Selisteanu D (2013) Adaptive and robust-adaptive control schemes for an anaerobic bioprocess with biogas production. 17th International Conference on System Theory, Control and Computing (ICSTCC), Sinaia 404-409

111. Harmand J, Manh AG, Steyer JP (2000) Identification and disturbance accommodating control of a fluidized bed anaerobic digester. Bioprocess Eng 23:177-185

112. Alvarez-Ramirez J, Meraz M, Monroy O, Velasco A (2002) Feedback control design for an anaerobic digestion process. J Chem Technol Biotechnol 77:725-734

113. Mendez-Acosta $\mathrm{HO}$ et al (2008) Robust control of volatile fatty acids in anaerobic digestion processes. Ind Eng Chem Res 47(20): $7715-7720$

114. Polit M, Estaben M, Labat P (2002) A fuzzy model for an anaerobic digester, comparison with experimental results. Eng Appl Artif Intell 15(5):385-390

115. Punal A, Rodriguez J, Franco A, Carrasco EF, Roca E, Lema JM (2003) Advanced monitoring and control of anaerobic wastewater treatment plants: diagnosis and supervision by a fuzzy-based expert system. Water Sci Technol 43(7):191-198

116. Yordanova ST (2004) Fuzzy two-level control for anaerobic wastewater treatment. Proc. 2nd IEEE International Conference on Intelligent Systems: 348-352

117. Mendez-Acosta HO, Campos-Delgado DU, Femat R, GonzalezAlvarez V (2005) A robust feedforward/feedback control for an anaerobic digester. Comput Chem Eng 29:1613-1623

118. Bastin G, Van Impe JF (1995) Nonlinear and adaptive control in biotechnology: a tutorial. Eur J Control 1(37):37-53

119. Renard P, Dochain D, Bastin G, Naveau H, Nyns EJ (1986) Adaptive control of anaerobic digestion processes: a pilot-scale approach. Biotechnol Bioeng 31:287-294

120. Theilliol D, Ponsart JC, Harmand J, Join C, Pascal G (2003) Online estimation of unmeasured inputs for anaerobic wastewater treatment process. Control Eng Pract 11:1007-1019

121. Steyer J, Buffiere P, Rolland D, Moletta R (1999) Advanced control of anaerobic digestion processes through disturbances monitoring. Water Res 33(9):2059-2068

122. Gaida D, et al. (2011) Optimal control of biogas plants using nonlinear model predictive control. Irish Signals and Systems Conference 2011

123. Boger Z (1997) Experience in industrial plant model development using large-scale artificial neural networks. Inf Sci 101(3-4):203216

124. Lindberg CF (1997) Control and estimation strategies applied to the activated sludge process. $\mathrm{PhD}$ thesis, Uppsala University, Finland

125. Alrawi RA, Ahmad A, Ismail NA, Kadir MO (2011) Anaerobic co-digestion of palm oil mill effluent with rumen fluid as co-substrate. Desalination 269:50-57

126. Demirer GN, Chen S (2005) Two-phased anaerobic digestion of unscreened dairy manure. Process Biochem 40:3542-3549 